dr hab. inż. Jarosław Prońko, prof. UJK ${ }^{1}$

st. bryg. w st. sp. mgr inż. Jan Kielin ${ }^{2}$

mgr Beata Wojtasiak ${ }^{2}$

Przyjęty/Accepted/Принята: 30.07.2015;

Zrecenzowany/Reviewed/Рецензирована: 27.08.2015;

Opublikowany/Published/Опубликована: 30.09.2015;

\title{
Klasyfikacja zdarzeń na podstawie danych historycznych ${ }^{3}$
}

\author{
Classification of Incidents on the Basis of Historical Data
}

\author{
Классификация событий на основе исторических данных
}

\begin{abstract}
ABSTRAKT
Cel: Opis metody klasyfikacji zdarzeń krytycznych stanowiącej uzupełnienie przestrzennej analizy zagrożeń.

Wprowadzenie: Klasyfikacja zdarzeń krytycznych pozwala na ocenę zdolności zorganizowanego systemu ratowniczo-gaśniczego do sprostania wymaganiom występującym na danym terenie. Powinna ona opierać się na analizie danych historycznych, ponieważ tylko one dają prawdziwy obraz występujących na danym terenie zdarzeń krytycznych. Co więcej w kontekście stabilności procesu ich pojawiania się, opisanego rozkładem Poissona, pozwalają przewidywać przyszłość w kilkuletniej perspektywie czasowej. Tym samym pozwalają ocenić zdolność systemu ratowniczo-gaśniczego do realizacji, na akceptowalny poziomie, stawianych przed nim zadań. Prezentowana w niniejszym artykule klasyfikacja zdarzeń krytycznych oparta została na naiwnym klasyfikatorze bayesowskim, który zakłada niezależność cech klasyfikacji. Pomimo swojej mylącej nazwy i prostoty założeń jest on bardzo skutecznym narzędziem klasyfikacji. W artykule zaprezentowano założenia metodyczne prowadzenia klasyfikacji zdarzeń krytycznych, opisano algorytm wykorzystania klasyfikacji zdarzeń krytycznych w przestrzennej analizie zagrożeń oraz zaprezentowano przykład takiej analizy dla jednego z powiatów. W badaniach wykorzystano dane zgromadzone w Systemie Wspomagania Decyzji dla Stanowisk Kierowania w wersji FireBird SWD-ST 2,5.

Metodologia: Analiza i prognozowanie statystyczne.

Wnioski: Cechami wyróżniającymi poszczególne incydenty krytyczne są: rodzaj zdarzenia; czas trwania działań ratowniczych; ilość użytych do działań ratowniczych sił i środków.

Wstępne wyróżnienie cech klasyfikacyjnych związane jest z istotą prowadzonych analiz, których głównym celem jest ocena adekwatności potencjału i czasowych możliwości reakcji systemu ratowniczo-gaśniczego. Dominującymi zatem cechami konstytuującymi daną kategorię zdarzeń będą:

- rodzaj zdarzenia definiowany pod kątem niezbędnego wyposażenia i wyszkolenia;

- wielkość zdarzenia definiowana pod kątem ilości sił i środków niezbędnych do prowadzenia skutecznej akcji ratowniczej i usuwania skutków. (Ponieważ analizy opierają się na danych historycznych należy zatem brać pod uwagę ilość zadysponowanych do danego zdarzenia sił i środków).

- czas trwania działań ratowniczych, który wspólnie z zadysponowanymi siłami i środkami definiuje wielkość zdarzenia.

Przeprowadzona analiza, której efekty jedynie w ograniczonym zakresie przedstawiono w niniejszym artykule, udowadnia słuszność przyjętych założeń.
\end{abstract}

Słowa kluczowe: analiza ryzyka, analiza statystyczna, prognozowanie statystyczne, klasyfikacja statystyczna Typ artykułu: oryginalny artykuł naukowy

\section{A B S T RACT}

Aim: To describe an approach in the classification of critical incidents, which are aggregated for a spatial analysis of threats. Introduction: Classification of critical incidents allows for a capability evaluation of an organized firefighting and rescue system, to meet the demands identified in a given area. It should be based on an analysis of historical data and only such information provides a realistic

Uniwersytet Jana Kochanowskiego w Kielcach / The Jan Kochanowski University in Kielce, Poland;

2 Centrum Naukowo-Badawcze Ochrony Przeciwpożarowej - Państwowy Instytut Badawczy, Józefów / Scientific and Research Centre for Fire Protection - National Research Institute, Poland; jkielin@cnbop.pl;

3 Wkład merytoryczny w powstanie artykułu / Percentage contribution: J. Prońko - 60\%, J. Kielin - 20\%, B. Wojtasiak - 20\%; 
representation of critical incidents, which occur in a given area. In the context of process stability, this profile can be illustrated by the Poisson distribution and will facilitate short term forecasting. Additionally, such data allows for performance evaluation of the firefighting and rescue system in context of tasks placed upon the system. The critical incident classification, presented in this article, is based on the naive Bayesian codifier, which assumes the independence of classification characteristics. Despite the misleading name and simplified assumptions, it is a very effective tool in the classification process. The article presents methodological assumptions for grading of critical events, describes the algorithm used for the codification of such incidents in the course of spatial threat analysis and provides an example of such an analysis for one of the districts. The study used data stored in the support system for decision making in Command and Control Centres, Fire Bird version 2.5 SWD-ST.

Methodology: Statistical analysis and forecasting.

Conclusions: The distinguishing features of critical incidents are: type of event, operation duration and volume of resources used during incidents. The initial distinction of classification features is linked to the essence of the analysis, whose main objective is to assess the adequacy of potential and timely response of the firefighting and rescue system. Therefore, dominant features for a given category of incident will be: type of event, defined in terms of required equipment and training; the size of incident, defined in terms of the volume of resources necessary to conduct an effective rescue operation. Since the analysis is based on historical data, it is necessary to take into account the volume of resources deployed to a given incident and finally; the duration for the operation, which together with resources used, defines the magnitude of the incident. The analysis and outcomes, of which a limited range is presented in this article, confirms the validity of assumptions.

Keywords: analysis of hazards, statistical analysis, statistical forecasting, statistical classification

Type of article: original scientific article

\section{АННОТАЦИЯ}

Цель: Описать метод классификации критических событий, который является дополнением пространственного анализа угроз.

Введение: Классификация критических событий позволяет оценить способность организованной спасательно-гасящей системы отвечать требованиям, характерным для данной территории. Классификация должна быть основана на анализе исторических данных, так как только они дают истинную картину происходящих на данной территории событий. В контексте стабильного процесса их регулярного появления, описанного распределением Пуассона, возникает возможность предсказать их на несколько лет вперед. Таким образом, они позволяют оценить способность спасательно-гасящей системы к реализации необходимых задач на допустимом уровне. Классификация критических событий представленная в статье основана на наивном байесовском классификаторе, который предполагает независимость характеристик классификации. Несмотря на свое обманчивое название и простые предположения, он является очень эффективным способом классификации. В статье представлены: методические предположения проведения классификации критических событий, описан алгоритм использования классификации критических событий в пространственном анализе угроз и представлен пример такого анализа для одного района (повята). В исследованиях были использованы данные, собранные в системе поддержки решений для позиций управления в версии FireBird SWD-ST 2,5.

Методология: статистический анализ и прогнозирование.

Выводы: Характеристиками, отличающими отдельные критические происшествия, являются: вид события, длительность спасательных действий, количество сил и средств, использованных при спасательной операции.

Предварительное определение характеристик классификации связано с сущностью проводимых анализов, целью которых является оценка адекватности потенциала и способности провести своевременные реакции спасательно-гасящей системы. Поэтому, доминирующими характеристиками, определяющими данную категорию будут:

- тип события, определяемый с точки зрения необходимого оборудования и обучения;

- масштаб события, определяемый с точки зрения сил и средств необходимых для проведения эффективного спасательного действия и ликвидации последствий события. В связи с тем, что анализы основаны на исторических данных, следует учитывать количество сил и средств, приделенных к данному событию.

- продолжительность спасательных действий, которая вместе с распределенными силами и средствами определяет масштаб события.

Проводимый анализ, эффекты которого только в ограниченном диапазоне представлены в данной статье, доказывает правильность принятых предположений.

Ключевые слова: анализ риска, статистический анализ, статистическое прогнозирование, статистическая классификация Вид статьи: оригинальная научная статья

\section{Wstęp}

W artykule pt. Przestrzenna analiza zagrożeń na podstawie danych historycznych (BiTP 39 Issue 3, 2015 pp. 77-92) zaprezentowano metodę analizy i predykcji zagrożeń na obszarze powiatu w oparciu o dane historyczne. Opiera się ona na udowodnionej stabilności (w krótkiej perspektywie czasowej kilku lat) procesu Poissona opisującego pojawianie się kolejnych zdarzeń krytycznych. Uzupełnieniem wyżej wspomnianej analizy jest klasyfikacja zdarzeń krytycznych, której uzasadnione metodycznie podstawy prezentuje niniejszy artykuł.

Właściwa klasyfikacja zdarzeń krytycznych pozwala na ocenę zdolności zorganizowanego systemu ratowniczo-gaśniczego do sprostania wymaganiom występującym na danym terenie. Powinna ona opierać się na analizie danych historycznych, ponieważ tylko one dają prawdziwy obraz 
występujących na danym terenie zdarzeń krytycznych. Z kolei w kontekście stabilności procesu ich pojawiania się, opisanego rozkładem Poissona, pozwalają przewidywać przyszłość w kilkuletniej perspektywie czasowej. Tym samym pozwalają ocenić zdolność systemu ratowniczo-gaśniczego do realizacji, na akceptowalnym poziomie, stawianych przed nim zadań.

Prezentowana w niniejszym artykule klasyfikacja zdarzeń krytycznych oparta została na naiwnym klasyfikatorze bayesowskim, który zakłada niezależność cech klasyfikacji. Pomimo swojej mylącej nazwy i prostoty założeń jest on bardzo skutecznym narzędziem klasyfikacji.

W artykule zaprezentowano założenia metodyczne prowadzenia klasyfikacji zdarzeń krytycznych, opisano algorytm wykorzystania klasyfikacji zdarzeń krytycznych w przestrzennej analizie zagrożeń oraz zaprezentowano przykład takiej analizy dla jednego z powiatów.

W badaniach wykorzystano dane zgromadzone w Systemie Wspomagania Decyzji dla Stanowisk Kierowania w wersji FireBird SWD-ST 2,5. W systemie tym rejestrowane są poszczególne incydenty krytyczne w zakresie: przestrzennym, czasowym, użytych sił i środków, skutków dla życia i zdrowia ofiar zdarzenia oraz ratowników, rodzaju i przyczyn zdarzenia. System ten pozwala w czasie rzeczywistym przyjmować zgłoszenia oraz obsługiwać zdarzenia w zakresie dysponowania sił i środków Państwowej Straży Pożarnej oraz Ochotniczej Straży Pożarnej funkcjonującej w ramach KSRG i poza nim.

W zakresie przestrzennym ujmuje się w nim: współrzędne geograficzne miejsca zdarzenia w układzie WGS 84; adres zdarzenia - gminę, miejscowość, ulicę oraz liczbę kilometrów przebytych przez jednostkę. Kategorie zdarzeń opisywane są według rodzaju (pożar, zagrożenia miejscowe) i wielkości (małe, średnie, duże). Uzupełnieniem tych informacji są wskazane opisowo przyczyny zdarzenia. W obszarze czasowym gromadzi się następujące dane: czas zauważenia, lokalizacji i usunięcia zdarzenia oraz czas zadysponowania jednostki ratowniczej, dotarcia przez nią do miejsca zdarzenia i powrotu ostatniej jednostki. Dane czasowe podawane są $\mathrm{z}$ dokładnością do jednej minuty. W zakresie użytych sił i środków podawane są zadysponowane siły i środki z podziałem na poszczególne rodzaje sprzętu.

\section{Wprowadzenie metodyczne}

Jak wspomniano, klasyfikacji dokonano metodą naiwnego klasyfikatora bayesowskiego. Przyjęto, że cechami, które wyróżniają poszczególne zdarzenia są:

- rodzaj zdarzenia;

- czas trwania działań ratowniczych;

- liczba użytych do działań ratowniczych sił i środków.

Założono, ze przyjęte cechy klasyfikacji są od siebie niezależne, co stanowi istotę tej metody, bez względu na fakt, czy owa zależność występuje, czy też nie.

Wstępne wyróżnienie cech klasyfikacyjnych związane jest $\mathrm{z}$ istotą prowadzonych analiz, których głównym celem jest ocena adekwatności potencjału i czasowych możliwości reakcji systemu ratowniczo-gaśniczego. Dominującymi zatem cechami konstytuującymi daną kategorię zdarzeń będą:

- rodzaj zdarzenia definiowany pod kątem niezbędnego wyposażenia i wyszkolenia;

- wielkość zdarzenia definiowana pod kątem liczby sił i środków niezbędnych do prowadzenia skutecznej akcji ratowniczej i usuwania skutków zdarzenia. Ponieważ analizy opierają się na danych historycznych, należy brać pod uwagę liczbę zadysponowanych do danego zdarzenia sił i środków. Klasyfikacja taka może być bardzo trudna ze względu na znaczną różnorodność danych w tym zakresie. Należy zatem przyjąć określone kryterium, np. liczbę standardowych jednostek podstawowych dysponowanych do danego zdarzenia, bez wnikania w specjalistyczne siły i środki dysponowane do zdarzenia. W przypadku straży pożarnej mogą to być pojazdy gaśnicze ze standardowym wyposażeniem i obsadą.

- czas trwania działań ratowniczych i usuwania skutków zdarzenia, który wspólnie z zadysponowanymi siłami i środkami definiuje wielkość zdarzenia.

Klasyfikowanie zdarzeń pod kątem cech istotnych dla celu analizy może napotykać szereg problemów, do rozwiązywania których możemy wykorzystać inne techniki badawcze, np. analizę ABC, wykresy pudełkowe, itp. Wybór właściwej techniki zależy od celu klasyfikacji.

Analiza ABC i jej odmiany opierają się na zasadzie V. Pareto. W ogólnym ujęciu, mówi ona, że w dużych zbiorach około $20 \%$ elementów decyduje o $80 \%$ efektów lub cech zbioru. W ujęciu statystycznym oznacza ona istnienie $\mathrm{w}$ rozkładzie danej cechy silnej koncentracji statystycznej. Zgodnie z zasadą Pareto krzywa Lorentza przechodzi przez punkt $(0,8 ; 0,2)$. Analiza taka nie tylko pozwala na podział danej kategorii zdarzeń na dwie lub trzy podkategorie, ale również pozwala wyeliminować ze zbioru analizowanych danych te, które znacznie różnią się od pozostałych. Różnice mogą wynikać ze specyfiki zdarzeń, błędnego ich opisu lub błędu decyzyjnego. Ten ostatni może być efektem zadysponowania zbyt dużych sił i środków do zdarzenia, które tego nie wymagało. Eliminacja zdarzeń znacznie różniących się od pozostałych danych $\mathrm{z}$ analizowanego zbioru jest niezbędna ze względu na zachowanie spójności kategorii. Należy jednak podchodzić do niej bardzo ostrożnie, bo być może odstające dane wskazują pewien nowy trend w kształtowaniu się analizowanego zjawiska. Problem właściwego doboru danych do analizy zawsze budzi szereg wątpliwości i często zależy wyłącznie od intuicji badacza i nie ma innych racjonalnych uzasadnień. Ich poszukiwanie wymaga dodatkowych żmudnych badań. Można przyjąć pewne mechanizmy doboru danych do analizy, ale w niektórych przypadkach mogą się one okazać zawodne, ponieważ odrzucone dane mogą wskazywać na nowe cechy jakościowe i ilościowe badanego zjawiska. Z drugiej zaś strony ich uwzględnienie w analizie może skutkować zafałszowaniem wyników, jeżeli przyjęte do analizy dane wynikają ze wskazanych powyżej błędów. 
Podobną techniką jest reprezentacja danej cechy analizowanych danych w postaci wykresów pudełkowych. Ich istotą jest reprezentacja danych empirycznych (np. czasu trwania działań ratowniczych) w postaci wykresu przedstawionego na ryc. 1. Główny obszar wykresu (pudełko, skrzynka) wskazuje 50\% realizacji danej cechy w badanym zjawisku. Kreska wewnątrz pudelka to mediana (Q2), jego brzegi to 1 i 3 kwantyl (Q1 i Q3); wąsy - kreski poza skrzynką - to 0 i 4 kwantyl (Q0 i Q4). Czasami wąsy te są zakończone punktami, które wskazują percentyl 0,95 (P 0,95) i 0,05 (P 0,05). Tak sporządzony wykres danych empirycznych opisujący rozkład analizowanej cechy pozwala z jednej strony sklasyfikować zdarzenia pod kątem analizowanej cechy w jednorodne i rozłączne grupy, z drugiej zaś pozwala na wykrycie danych znacznie różniących się od innych (percentyl 0,95 i 0,05).

Opisane powyżej techniki analizy danych pozwalają na wyodrębnienie rozłącznych, pod względem analizowanych cech, kategorii zdarzeń oraz ułatwiają wybór danych poddawanych dalszym analizom.

Kategoryzacja zdarzeń, pod względem cech wynikających z celu analizy, powinna doprowadzić do podziału zdarzeń na wyraźnie różniące się - rozłączne - pod względem analizowanych cech klasy. Przykład kategoryzacji zdarzeń przedstawiono w dalszej części artykułu.

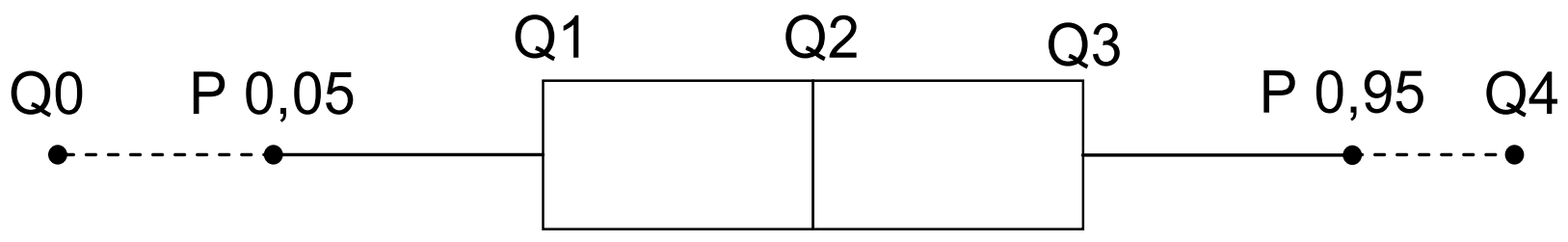

Ryc. 1. Zasady tworzenia wykresu pudełkowego

Fig. 1. The rules for creating a block diagram

Źródło: Opracowanie własne.

Source: Own elaboration.

Kategoryzacja zdarzeń ma ogromny wpływ na interpretację otrzymanych wyników, dlatego też powinna być bardzo szczegółowo opisana w każdej analizie przestrzennej zagrożeń miejscowych.

Prezentowana poniżej klasyfikacja zdarzeń opiera się na danych empirycznych zgromadzonych w bazie SWD-ST. Przyjęto, że każda klasa powinna zawierać w miarę jednorodne zdarzenia pod względem: rodzaju, czasu trwania akcji i ilości użytych sił i środków. Jako wyznacznik liczby użytych sił i środków przyjęto liczbę zaangażowanych pojazdów: $z$ jednostek ratowniczo-gaśniczych oraz ochotniczych straży pożarnych. Pozostałe rodzaje pojazdów i sprzętu używane były bardzo sporadycznie. Nieuwzględnienie ich w prowadzonych poniżej analizach statystycznych nie ma zatem wpływu na wiarygodność otrzymanych wyników, w aspekcie prawdopodobieństwa występowania poszczególnych klas zagrożeń.

\section{Klasyfikacja zdarzeń krytycznych}

\subsection{Rodzaj zdarzenia}

W bazie danych SWD-ST występuje podział na pożary i inne zagrożenia miejscowe.

Jednakże w przypadku innych zagrożeń miejscowych należy dokonać bardziej szczegółowej klasyfikacji. W rubryce (baza danych SWD-ST): przyczyny powstania zdarzenia można znaleźć wpisy pozwalające wstępnie podzielić zdarzenia na:

- kolizje i wypadki komunikacyjne;

- usuwanie skutków: podtopień powstałych w wyniku: gwałtownych roztopów lub opadów deszczu, silnego wiatru, gwałtownych opadów śniegu, gołoledzi itp.;
- usuwanie: gniazd owadów, skutków awarii; umożliwianie dostępu do pomieszczeń, ratowanie zwierząt itp.;

- zabezpieczanie imprez masowych, ćwiczenia, zabezpieczanie lądowania helikopterów itp.

Każdy z prezentowanych rodzajów zdarzeń wymaga innego czasu i zaangażowanych sił i środków. Wskazuje to na potrzebę podziału ich na klasy, w których rozkłady empiryczne: czasu trwania akcji i liczby zaangażowanych sił i środków są stabilne, przy jednoczesnym spełnieniu warunku wiarygodności wnioskowania statystycznego - odpowiedniej ilości danych empirycznych reprezentujących daną klasę.

\subsection{Pożary}

Klasyfikacji pożarów dokonano w oparciu o analizę liczby zaangażowanych pojazdów gaśniczych uzupełnioną analizą czasu trwania akcji ratowniczej. Przyjęto następujące założenia wstępne (założenia analizy ABC opartej na zasadzie V. Pareto):

- około $80 \%$ to pożary małe;

- około $15 \%$ to pożary średnie;

- około 5\% to pożary duże.

Zestawienie liczby pożarów i liczby zaangażowanych pojazdów gaśniczych przedstawiono w tabeli 1 . 
Tabela 1. Klasyfikacja pożarów według wielkości - kryterium: liczba użytych pojazdów gaśniczych dla badanego powiatu Table 1. Classification of fires by size - criterion: the number of firefighting vehicles used for the analysed district

\begin{tabular}{|c|c|c|c|c|c|c|c|c|c|c|}
\hline \multirow[b]{2}{*}{  } & \multicolumn{3}{|c|}{2008} & \multicolumn{3}{|c|}{2009} & \multicolumn{3}{|c|}{2010} & \\
\hline & 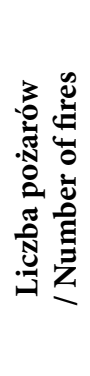 & 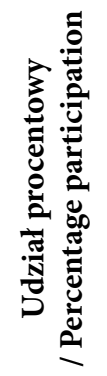 & 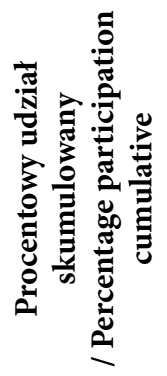 &  & 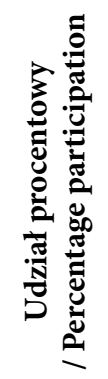 &  & 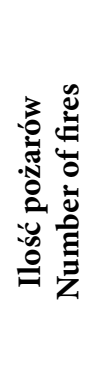 &  & 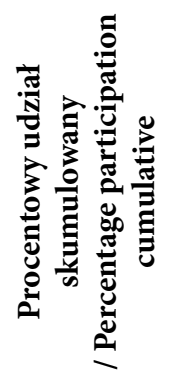 & \\
\hline 1 & 412 & $66,7 \%$ & $66,7 \%$ & 325 & $62,0 \%$ & $62,0 \%$ & 432 & $64,2 \%$ & $64,2 \%$ & \multirow{2}{*}{ 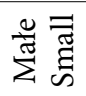 } \\
\hline 2 & 98 & $15,9 \%$ & $82,5 \%$ & 97 & $18,5 \%$ & $80,5 \%$ & 137 & $20,4 \%$ & $84,5 \%$ & \\
\hline 3 & 43 & $7,0 \%$ & $89,5 \%$ & 48 & $9,2 \%$ & $89,7 \%$ & 45 & $6,7 \%$ & $91,2 \%$ & \multirow{3}{*}{ 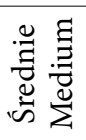 } \\
\hline 4 & 26 & $4,2 \%$ & $93,7 \%$ & 19 & $3,6 \%$ & $93,3 \%$ & 17 & $2,5 \%$ & $93,8 \%$ & \\
\hline 5 & 19 & $3,1 \%$ & $96,8 \%$ & 15 & $2,9 \%$ & $96,2 \%$ & 12 & $1,8 \%$ & $95,5 \%$ & \\
\hline 6 & 6 & $1,0 \%$ & $97,7 \%$ & 7 & $1,3 \%$ & $97,5 \%$ & 10 & $1,5 \%$ & $97,0 \%$ & \multirow{12}{*}{  } \\
\hline 7 & 3 & $0,5 \%$ & $98,2 \%$ & 4 & $0,8 \%$ & $98,3 \%$ & 11 & $1,6 \%$ & $98,7 \%$ & \\
\hline 8 & 2 & $0,3 \%$ & $98,5 \%$ & 3 & $0,6 \%$ & $98,9 \%$ & 4 & $0,6 \%$ & $99,3 \%$ & \\
\hline 9 & 3 & $0,5 \%$ & $99,0 \%$ & 0 & $0,0 \%$ & $98,9 \%$ & 2 & $0,3 \%$ & $99,6 \%$ & \\
\hline 10 & 1 & $0,2 \%$ & $99,2 \%$ & 2 & $0,4 \%$ & $99,2 \%$ & 0 & $0,0 \%$ & $99,6 \%$ & \\
\hline 11 & 1 & $0,2 \%$ & $99,4 \%$ & 3 & $0,6 \%$ & $99,8 \%$ & 0 & $0,0 \%$ & $99,6 \%$ & \\
\hline 12 & 2 & $0,3 \%$ & $99,7 \%$ & 0 & $0,0 \%$ & $99,8 \%$ & 0 & $0,0 \%$ & $99,6 \%$ & \\
\hline 13 & 0 & $0,0 \%$ & $99,7 \%$ & 0 & $0,0 \%$ & $99,8 \%$ & 1 & $0,1 \%$ & $99,7 \%$ & \\
\hline 14 & 0 & $0,0 \%$ & $99,7 \%$ & 0 & $0,0 \%$ & $99,8 \%$ & 1 & $0,1 \%$ & $99,9 \%$ & \\
\hline 15 & 0 & $0,0 \%$ & $99,7 \%$ & 0 & $0,0 \%$ & $99,8 \%$ & 1 & $0,1 \%$ & $100,0 \%$ & \\
\hline 19 & 1 & $0,2 \%$ & $99,8 \%$ & 1 & $0,2 \%$ & $100,0 \%$ & 0 & $0,0 \%$ & $100,0 \%$ & \\
\hline 21 & 1 & $0,2 \%$ & $100,0 \%$ & 0 & $0,0 \%$ & $100,0 \%$ & 0 & $0,0 \%$ & $100,0 \%$ & \\
\hline
\end{tabular}

Źródło: Opracowanie własne na podstawie danych z bazy SWD-ST.

Source: Own elaboration on the basis of data from the database SWD-ST.

Z zaprezentowanego w tabeli 1. zestawienia oraz przy uwzględnieniu zasady V. Pareto należy stwierdzić, że:

- pożary małe to takie, do których gaszenia zaangażowano do 2 pojazdów gaśniczych - stanowią one około $80 \%$ wszystkich zarejestrowanych w danym roku pożarów;

- pożary średnie to takie, do których gaszenia zaangażowano od 3 do 5 pojazdów gaśniczych - stanowią one około $15 \%$ wszystkich zarejestrowanych w danym roku pożarów;

- pożary duże to takie, do których gaszenia zaangażowano więcej niż 5 pojazdów gaśniczych - stanowią one około 5\% wszystkich zarejestrowanych w danym roku pożarów.

Dla innych obszarów powyższa klasyfikacja może przedstawiać się nieco inaczej, z innym podziałem na liczbę wykorzystanych sił i środków. Wynika to oczywiście ze specyfiki danego obszaru, na który składają się: tradycja dysponowania sił i środków do zdarzeń (wiedza i umiejętności dyspozytorów); rodzaje pożarów (w niektórych regionach mogą one wymagać większej liczby sił i środków niż w innych). Dlatego też wnioski z analizy jednego obszaru nie mogą być wykorzystywane do podejmowania decyzji na innych obszarach. Wskazują one również na rozbieżności w wyszkoleniu dyspozytorów i uwarunkowaniach poszczególnych regionów. Porównywanie obszarów należy zatem prowadzić w oparciu o dogłębną analizę tych uwarunkowań.

Klasyfikację tę należy uzupełnić o analizę czasu trwania akcji ratowniczej, którego długość powinna być skorelowana $\mathrm{z}$ dokonanym wcześniej podziałem. Zestawienie liczbowe przeprowadzonej analizy czasowej przedstawiono w tabeli 2 . 
Tabela 2. Rozkłady czasu trwania akcji ratowniczej w poszczególnych klasach pożarów na przestrzeni lat 2008-2010

Table 2. Duration of rescue operation in various classes of fires during the years 2008-2010

\begin{tabular}{|l|c|c|c|c|c|c|c|c|c|}
\hline \multicolumn{1}{|c|}{ Wielkość / Magnitude } & \multicolumn{3}{c|}{ Mały / Small } & \multicolumn{3}{c|}{ Średni / Medium } & \multicolumn{3}{c|}{ Duży / Large } \\
\hline \multicolumn{1}{|c|}{ Rok/Year } & $\mathbf{2 0 0 8}$ & $\mathbf{2 0 0 9}$ & $\mathbf{2 0 1 0}$ & $\mathbf{2 0 0 9}$ & $\mathbf{2 0 1 0}$ & $\mathbf{2 0 1 1}$ & $\mathbf{2 0 0 9}$ & $\mathbf{2 0 1 0}$ & $\mathbf{2 0 1 1}$ \\
\hline $\begin{array}{l}\text { kwartyl 0 (minimalna wartość) } \\
\text { quartile 0 (min value) }\end{array}$ & 5 & 4 & 7 & 12 & 15 & 19 & 45 & 62 & 129 \\
\hline $\begin{array}{l}\text { percentyl 0,05 } \\
\text { percentile 0,05 }\end{array}$ & 11,2 & 11,2 & 12,7 & 26,4 & 25,75 & 26,65 & 67,5 & 104,5 & 129,45 \\
\hline $\begin{array}{l}\text { kwartyl 1 (25\% zdarzeń) } \\
\text { quartile 1 (25\% of incidents) }\end{array}$ & 32 & 32 & 31,3 & 54,3 & 53,25 & 55,25 & 105,8 & 132,75 & 144,75 \\
\hline $\begin{array}{l}\text { kwartyl 2 (50\% zdarzeń) (mediana) } \\
\text { quartile 2 (50\% of incidents) }\end{array}$ & 58 & 58 & 54,5 & 89,5 & 90,5 & 87 & 149 & 189 & 254,5 \\
\hline $\begin{array}{l}\text { kwartyl 3 (75\% zdarzeń) } \\
\text { quartile 3 (75\% of incidents) }\end{array}$ & 97 & 91 & 89,8 & 130 & 156,75 & 147,5 & 319 & 321 & 448 \\
\hline $\begin{array}{l}\text { percentyl 0,95 } \\
\text { percentile 0,95 }\end{array}$ & 158 & 154 & 134 & 239 & 281,25 & 305,7 & 697,3 & 791,85 & 608,3 \\
\hline $\begin{array}{l}\text { kwartyl 4 (maksymalna wartość) } \\
\text { quartile 4 (maximum frequency of incidents) }\end{array}$ & 190 & 200 & 304 & 267 & 413 & 425 & 1384 & 995 & 647 \\
\hline
\end{tabular}

Źródło: Opracowanie własne na podstawie danych z bazy SWD-ST.

Source: Own elaboration on the basis of data from the database SWD-ST.

W zaprezentowanym w tabeli 2. zestawieniu wyraźnie widać dużą zbieżność rozkładu czasu trwania akcji ratowniczej z rodzajem pożaru określonym na podstawie liczby zaangażowanych pojazdów gaśniczych. Rozkłady czasu trwania akcji w przypadku małych pożarów są niemal identyczne w poszczególnych latach. Zgodność rozkładów dla pożarów średnich i dużych jest również wysoka zważywszy na fakt, iż stanowią one zaledwie 15\% i 5\% wszystkich pożarów w danym roku. Porównując mediany rozkładów czasu trwania akcji w zależności od wielkości pożaru, dostrzegamy również wyraźną korelację: mediana dla pożaru dużego jest dwa razy dłuższa od mediany dla pożaru średniego, a ta $\mathrm{z}$ kolei jest dwa razy dłuższa od mediany dla pożaru małego. Świadczy to o ścisłym związku między czasem trwania akcji ratowniczej a ilością zaangażowanych pojazdów gaśniczych. Zależności te jeszcze wyraźniej widać na wykresach skrzynkowych rozkładu czasu trwania działań ratowniczych, które przedstawiono na ryc. 2.

Linie ciągłe obrazują 20\% przypadków po odrzuceniu skrajnych (z lewej i prawej strony) 5\% przypadków. Odrzucając wartości skrajne (nie reprezentowane na wykresie), dostrzegamy dużą zbieżność rozkładów czasu trwania akcji, szczególnie w przypadku małych pożarów oraz silną zależność czasu trwania akcji od klasy pożaru: mały, średni i duży.

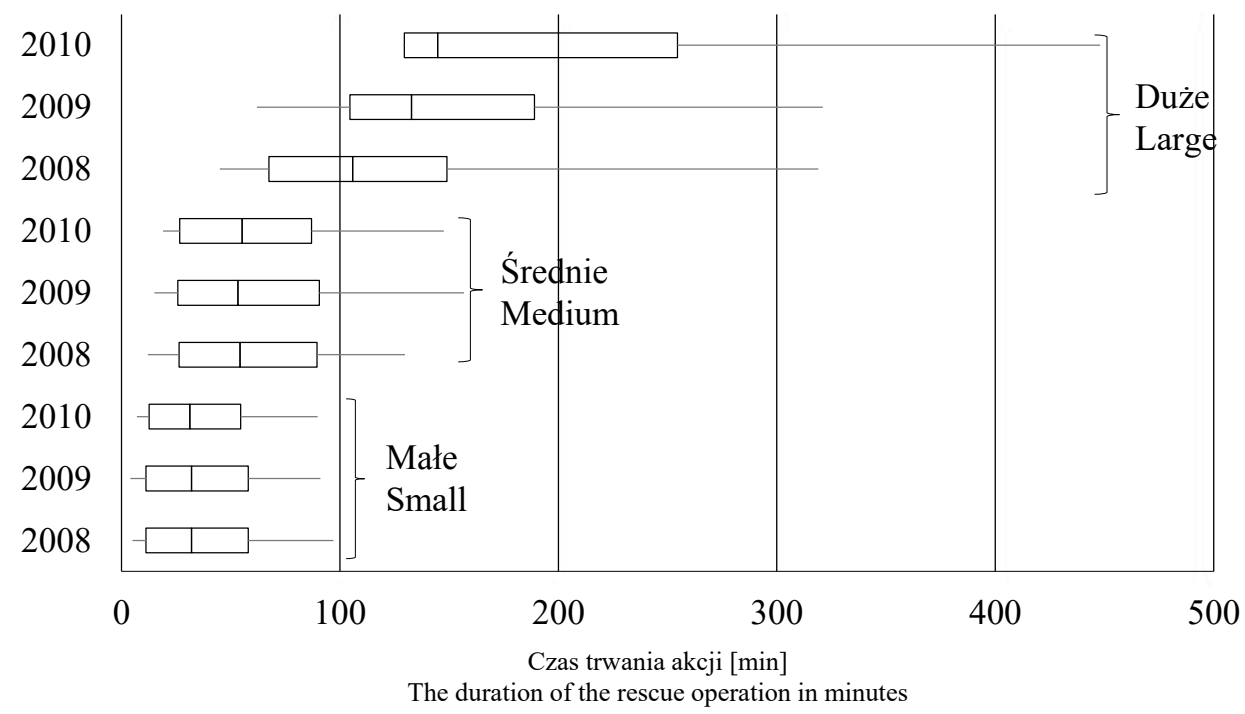

Ryc. 2. Wykresy skrzynkowe rozkładu czasu trwania akcji ratowniczej z podziałem na kategorie w latach 2009-2011

Fig. 2. Block diagrams illustrating the duration of rescue operations by type for years 2009-2011

Źródło: Opracowanie własne na podstawie danych z bazy SWD-ST.

Source: Own elaboration on the basis of data from the database SWD-ST.

Należy zatem uznać, że dokonana klasyfikacja wielkości pożarów według przyjętych kryteriów jest poprawna. Można zatem przyjąć następujący podział pożarów, w którym głównym wyznacznikiem jest liczba zaangażowanych pojazdów: 
- małe - liczba zaangażowanych pojazdów gaśniczych do 2, czas trwania akcji ratowniczej zawiera się w przedziale od $12 \mathrm{~min}$ do $150 \mathrm{~min}$, na poziomie ufności 0,95 ; stanowią one około $80 \%$ wszystkich pożarów w danym roku;

- średni - liczba zaangażowanych pojazdów gaśniczych od 3 do 5, czas trwania akcji ratowniczej zawiera się w przedziale od $25 \mathrm{~min}$ do $300 \mathrm{~min}$, na poziomie ufności 0,95 ; stanowią one około $15 \%$ wszystkich pożarów w danym roku;

- duży - liczba zaangażowanych pojazdów gaśniczych powyżej 5, czas trwania akcji ratowniczej zawiera się w przedziale od $70 \mathrm{~min}$ do $700 \mathrm{~min}$, na poziomie ufności 0,95 ; stanowią one około 5\% wszystkich pożarów w danym roku;

Należy jednak zaznaczyć, że klasyfikacja ta może być stosowana do prognozowania przyszłych zdarzeń na obszarze badanego powiatu. W przypadku prowadzenia analiz dla innych obszarów i przedziałów czasowych należałoby sprawdzić, czy przyjęte kryterium spełnia zasadę V. Pareto.

\subsection{Miejscowe zagrożenia}

Zastosowanie powyższej procedury dla miejscowych zagrożeń jest możliwe dopiero po ich klasyfikacji na możliwie jednorodne zdarzenia. Szczegółowa analiza danych z systemu SWD-ST pozwoliła dokonać podziału miejscowych zagrożeń na następujące klasy:

- kolizje i wypadki komunikacyjne;

- usuwanie skutków działania sił natury (gołoledź, nadmierne opady deszczu, roztopy, silny wiatr, itp.);

- inne zdarzenia (wśród nich dominuje usuwanie niepożądanych owadów, ponadto w klasie tej mieszczą się: awarie, udostępnianie dotarcia do zamkniętych pomieszczeń, przyczyny nieustalone, pomoc policji; itp.);

- zabezpieczenie i ćwiczenia (zabezpieczenie: imprez masowych, lądowania helikoptera, ćwiczeń z materiałami niebezpiecznymi; ćwiczenia własne jednostek ratowniczych, itp.).

W dalszych analizach nie brano pod uwagę ostatniej klasy zdarzeń (zabezpieczenie i ćwiczenia), ze względu na jej deterministyczny, a nie stochastyczny charakter. Analizie poddano zdarzenia $\mathrm{z}$ roku 2009, a następnie porównano je z danymi z roku 2011. Zestawienie liczby zdarzeń miejscowych w rozbiciu na kategorie przedstawiono w tabeli 3 .

Dane z tabeli 3. wskazują na znaczną trudność podziału tych zdarzeń na małe, średnie i duże $\mathrm{z}$ wykorzystaniem zasady V. Pareto. Jedynie w przypadku potraktowania wszystkich jako jednej grupy istnieje taka możliwość.

Tabela 3. Zestawienie liczby miejscowych zagrożeń w rozbiciu na kategorie w roku 2009 na terenie badanego powiatu Table 3. Number of local hazards, by type in 2009 for the analysed district

\begin{tabular}{|c|c|c|c|c|c|c|c|c|c|c|c|c|}
\hline \multirow[b]{2}{*}{ 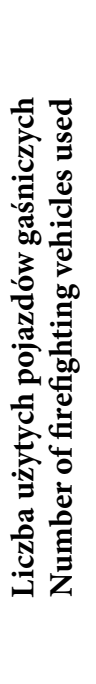 } & \multicolumn{3}{|c|}{$\begin{array}{c}\text { Kolizje i wypadki } \\
\text { komunikacyjne / } \\
\text { Road traffic accidents }\end{array}$} & \multicolumn{3}{|c|}{$\begin{array}{c}\text { Usuwanie skutków } \\
\text { działania sił natury / } \\
\text { Removal of effects caused } \\
\text { by forces of nature }\end{array}$} & \multicolumn{3}{|c|}{$\begin{array}{l}\text { Inne zdarzenia / } \\
\text { Other incidents }\end{array}$} & \multicolumn{3}{|c|}{ Razem / Total } \\
\hline & 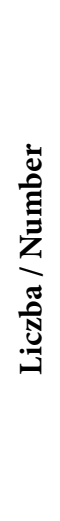 &  & 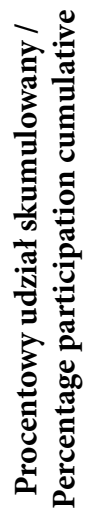 &  &  & 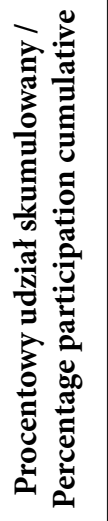 &  &  &  & 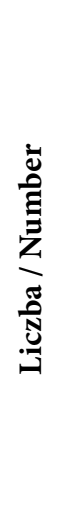 & 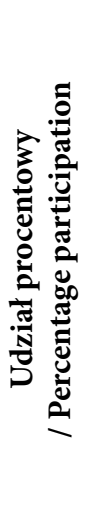 &  \\
\hline 1 & 72 & $49 \%$ & $49 \%$ & 207 & $69 \%$ & $69 \%$ & 373 & $87 \%$ & $87 \%$ & 652 & $75 \%$ & $75 \%$ \\
\hline 2 & 41 & $28 \%$ & $77 \%$ & 73 & $24 \%$ & $94 \%$ & 41 & $10 \%$ & $96 \%$ & 155 & $18 \%$ & $92 \%$ \\
\hline 3 & 30 & $21 \%$ & $98 \%$ & 16 & $5 \%$ & $99 \%$ & 8 & $2 \%$ & $98 \%$ & 54 & $6 \%$ & $99 \%$ \\
\hline 4 & 3 & $2 \%$ & $100 \%$ & 1 & $0 \%$ & $100 \%$ & 2 & $0 \%$ & $99 \%$ & 6 & $1 \%$ & $99 \%$ \\
\hline 5 & 0 & $0 \%$ & $100 \%$ & 0 & $0 \%$ & $100 \%$ & 3 & $1 \%$ & $99 \%$ & 3 & $0 \%$ & $100 \%$ \\
\hline 6 & 0 & $0 \%$ & $100 \%$ & 0 & $0 \%$ & $100 \%$ & 2 & $0 \%$ & $100 \%$ & 2 & $0 \%$ & $100 \%$ \\
\hline 8 & 0 & $0 \%$ & $100 \%$ & 1 & $0 \%$ & $100 \%$ & 1 & $0 \%$ & $100 \%$ & 2 & $0 \%$ & $100 \%$ \\
\hline
\end{tabular}

Źródło: Opracowanie własne na podstawie danych $\mathrm{z}$ bazy SWD-ST.

Source: Own elaboration on the basis of data from the database SWD-ST.

Wyróżniane klasy zdarzeń powinny wykazywać również znaczną odrębność pod względem czasu trwania działań ratowniczych. W tabeli 4. oraz na ryc. 2. przedstawiono zestawienie analizy czasu trwania działań ratowniczych. 
Tabela 4. Zestawienie wyników analizy czasu trwania akcji ratowniczej w przypadku różnych rodzajów zdarzeń przy różnej ilości zaangażowanych sił i środków (dane z roku 2009)

Table 4. Analysis results revealing the duration of rescue operation for different type of incidents with varying volumes of used resources (data from 2009)

\begin{tabular}{|c|c|c|c|c|c|c|c|c|}
\hline & 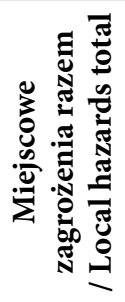 & 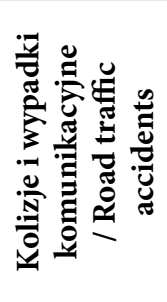 & 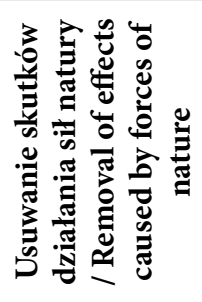 & 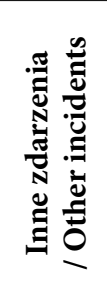 & 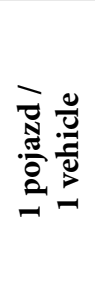 & 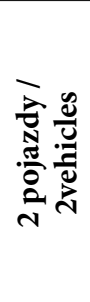 & 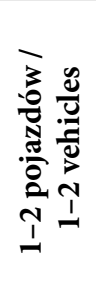 & 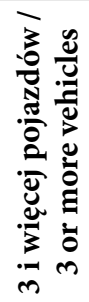 \\
\hline $\begin{array}{l}\text { kwartyl } 0 \\
\text { quartile } 0 \\
\end{array}$ & 3 & 10 & 3 & 9 & 3 & 9 & 3 & 14 \\
\hline $\begin{array}{l}\text { percentyl } 0,05 \\
\text { percentile } 0,05\end{array}$ & 22 & 23,25 & 21 & 22 & 21 & 28,7 & 21,35 & 37,9 \\
\hline $\begin{array}{l}\text { kwartyl } 1 \\
\text { quartile } 1\end{array}$ & 42 & 46,25 & 41 & 42 & 39 & 54,5 & 41 & 74 \\
\hline $\begin{array}{l}\text { kwartyl } 2 \\
\text { quartile } 2\end{array}$ & 62 & 73 & 65,5 & 58 & 57 & 76 & 60 & 130 \\
\hline $\begin{array}{l}\text { kwartyl } 3 \\
\text { quartile } 3\end{array}$ & 98 & 124,25 & 114,75 & 79 & 80 & 127,5 & 88 & 188 \\
\hline $\begin{array}{l}\text { percentyl } 0,95 \\
\text { percentile } 0,95\end{array}$ & 189,5 & 260,75 & 200,6 & 146,55 & 152,4 & 226,5 & 166,3 & 829,7 \\
\hline $\begin{array}{l}\text { kwartyl } 4 \\
\text { quartile } 4\end{array}$ & 4620 & 995 & 1171 & 4620 & 504 & 386 & 504 & 4620 \\
\hline
\end{tabular}

Źródło: Opracowanie własne na podstawie danych z bazy SWD-ST.

Source: Own elaboration on the basis of data from the database SWD-ST.

Zaprezentowane wyniki analiz wyraźnie wskazują na brak różnic między przyjętymi klasami zdarzeń w układzie rodzajowym. Dość wyraźna różnica pojawia się jedynie przy analizie cechy: liczba zaangażowanych pojazdów. Podczas analizy ryc. 3. łatwo zauważyć wyraźną różnicę w czasie trwania działań ratowniczych między zdarzeniami, w czasie których zaangażowano do dwóch pojazdów a tymi, w których użyto trzech i więcej. Jako główny wyznacznik różnic między klasami przyjęto odległość między medianami poszczególnych klas - metoda ważonych środków ciężkości.



Ryc. 3. Zobrazowanie danych z tabeli 4 . w postaci wykresów skrzynkowych (na wykresach nie uwzględniono kwartylu 0 i 4 )

Fig. 3. Block diagram of data from Table 4 (quartile 0 and 4 excluded from the diagram)

Źródło: Opracowanie własne na podstawie danych z bazy SWD-ST.

Source: Own elaboration on the basis of data from the database SWD-ST. 
Podobne własności wykazują dane z roku 2011. Wyniki analizy zaprezentowano w tabeli 5 i 6 oraz na ryc. 4.

Tabela 5. Zestawienie miejscowych zagrożeń w układzie rodzajowym w roku 2011 dla powiatu otwockiego

Table 5. Number of local hazards by type in 2011 for the district of Otwock

\begin{tabular}{|c|c|c|c|c|c|c|c|c|c|c|c|c|}
\hline \multirow{2}{*}{ 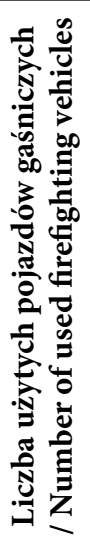 } & \multicolumn{3}{|c|}{$\begin{array}{c}\text { Kolizje i wypadki } \\
\text { komunikacyjne / } \\
\text { Road traffic accidents }\end{array}$} & \multicolumn{3}{|c|}{$\begin{array}{c}\text { Usuwanie skutków } \\
\text { działania sił natury / } \\
\text { Removal of effects caused } \\
\text { by forces of nature }\end{array}$} & \multicolumn{3}{|c|}{$\begin{array}{l}\text { Inne zdarzenia / } \\
\text { Other incidents }\end{array}$} & \multicolumn{3}{|c|}{ Razem / Total } \\
\hline & 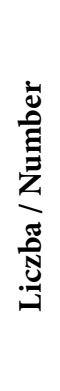 & 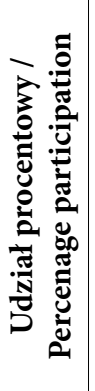 & 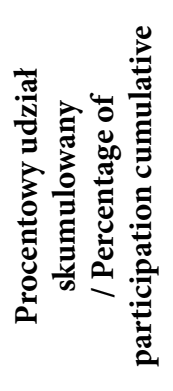 & 㟧 & 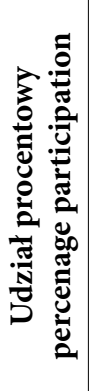 & 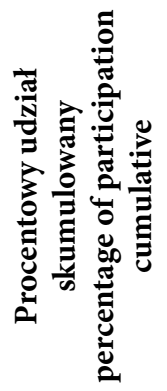 & 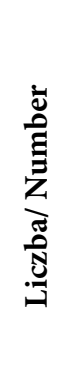 & 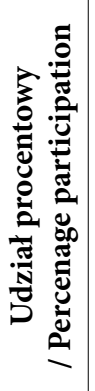 & 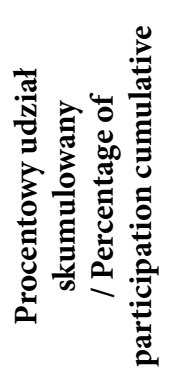 & 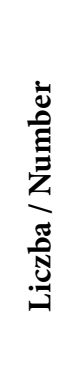 & 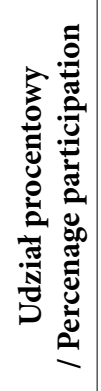 & 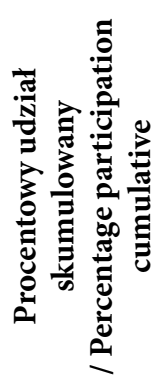 \\
\hline 1 & 83 & $55 \%$ & $55 \%$ & 276 & $73 \%$ & $73 \%$ & 308 & $79 \%$ & $79 \%$ & 667 & $73 \%$ & $73 \%$ \\
\hline 2 & 37 & $25 \%$ & $79 \%$ & 69 & $18 \%$ & $91 \%$ & 60 & $15 \%$ & $94 \%$ & 166 & $18 \%$ & $91 \%$ \\
\hline 3 & 22 & $15 \%$ & $94 \%$ & 15 & $4 \%$ & $95 \%$ & 14 & $4 \%$ & $98 \%$ & 51 & $6 \%$ & $96 \%$ \\
\hline 4 & 8 & $5 \%$ & $99 \%$ & 4 & $1 \%$ & $96 \%$ & 6 & $2 \%$ & $99 \%$ & 18 & $2 \%$ & $98 \%$ \\
\hline 5 & 1 & $1 \%$ & $100 \%$ & 1 & $0 \%$ & $97 \%$ & 2 & $1 \%$ & $100 \%$ & 4 & $0 \%$ & $98 \%$ \\
\hline 6 & 0 & $0 \%$ & $100 \%$ & 4 & $1 \%$ & $98 \%$ & 1 & $0 \%$ & $100 \%$ & 5 & $1 \%$ & $99 \%$ \\
\hline 7 & 0 & $0 \%$ & $100 \%$ & 4 & $1 \%$ & $99 \%$ & 0 & $0 \%$ & $100 \%$ & 4 & $0 \%$ & $99 \%$ \\
\hline 9 & 0 & $0 \%$ & $100 \%$ & 2 & $1 \%$ & $99 \%$ & 0 & $0 \%$ & $100 \%$ & 2 & $0 \%$ & $100 \%$ \\
\hline 10 & 0 & $0 \%$ & $100 \%$ & 1 & $0 \%$ & $99 \%$ & 0 & $0 \%$ & $100 \%$ & 1 & $0 \%$ & $100 \%$ \\
\hline 12 & 0 & $0 \%$ & $100 \%$ & 1 & $0 \%$ & $100 \%$ & 0 & $0 \%$ & $100 \%$ & 1 & $0 \%$ & $100 \%$ \\
\hline 22 & 0 & $0 \%$ & $100 \%$ & 1 & $0 \%$ & $100 \%$ & 0 & $0 \%$ & $100 \%$ & 1 & $0 \%$ & $100 \%$ \\
\hline
\end{tabular}

Źródło: Opracowanie własne na podstawie danych $\mathrm{z}$ bazy SWD-ST.

Source: Own elaboration on the basis of data from the database SWD-ST.

Tabela 6. Zestawienie wyników analizy czasu trwania akcji ratowniczej w przypadku różnych rodzajów zdarzeń przy różnej liczby zaangażowanych sił i środków (dane z roku 2011)

Table 6. Analysis results revealing the duration of rescue operation for different type of incidents with varying volumes of used resources (data from 2011)

\begin{tabular}{|c|c|c|c|c|c|c|c|c|}
\hline & 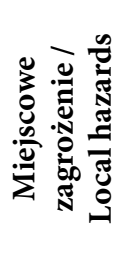 & 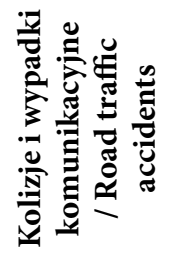 & 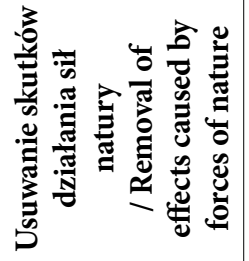 & 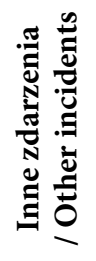 & 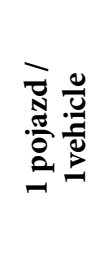 & 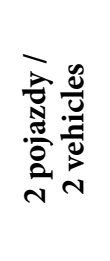 & 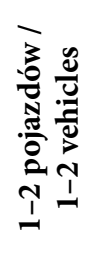 & 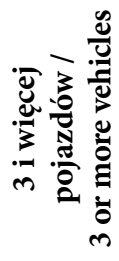 \\
\hline $\begin{array}{l}\text { kwartyl } 0 \\
\text { quartile } 0\end{array}$ & 4 & 14 & 4 & 11 & 4 & 20 & 4 & 32 \\
\hline $\begin{array}{l}\text { percentyl } 0,05 \\
\text { percentile } 0,05\end{array}$ & 23 & 24 & 23 & 22,35 & 22 & 31,4 & 23 & 67,6 \\
\hline $\begin{array}{l}\text { kwartyl } 1 \\
\text { quartile } 1\end{array}$ & 47 & 40 & 58 & 43,75 & 40 & 65 & 44 & 144 \\
\hline $\begin{array}{l}\text { kwartyl } 2 \\
\text { quartile } 2\end{array}$ & 81 & 66 & 106,5 & 65 & 68 & 103,5 & 74 & 233 \\
\hline $\begin{array}{l}\text { kwartyl } 3 \\
\text { quartile } 3\end{array}$ & 137,5 & 115,5 & 184,5 & 97 & 111,25 & 159,75 & 120 & 384 \\
\hline $\begin{array}{l}\text { percentyl } 0,95 \\
\text { percentile } 0,95\end{array}$ & 345,7 & 242 & 525,8 & 254,3 & 214,45 & 346,6 & 269,3 & 1416 \\
\hline $\begin{array}{l}\text { kwartyl } 4 \\
\text { quartile } 4\end{array}$ & 4950 & 432 & 4950 & 650 & 1158 & 1216 & 1216 & 4950 \\
\hline
\end{tabular}

Źródło: Opracowanie własne na podstawie danych z bazy SWD-ST

Source: Own elaboration on the basis of data from the database SWD-ST. 


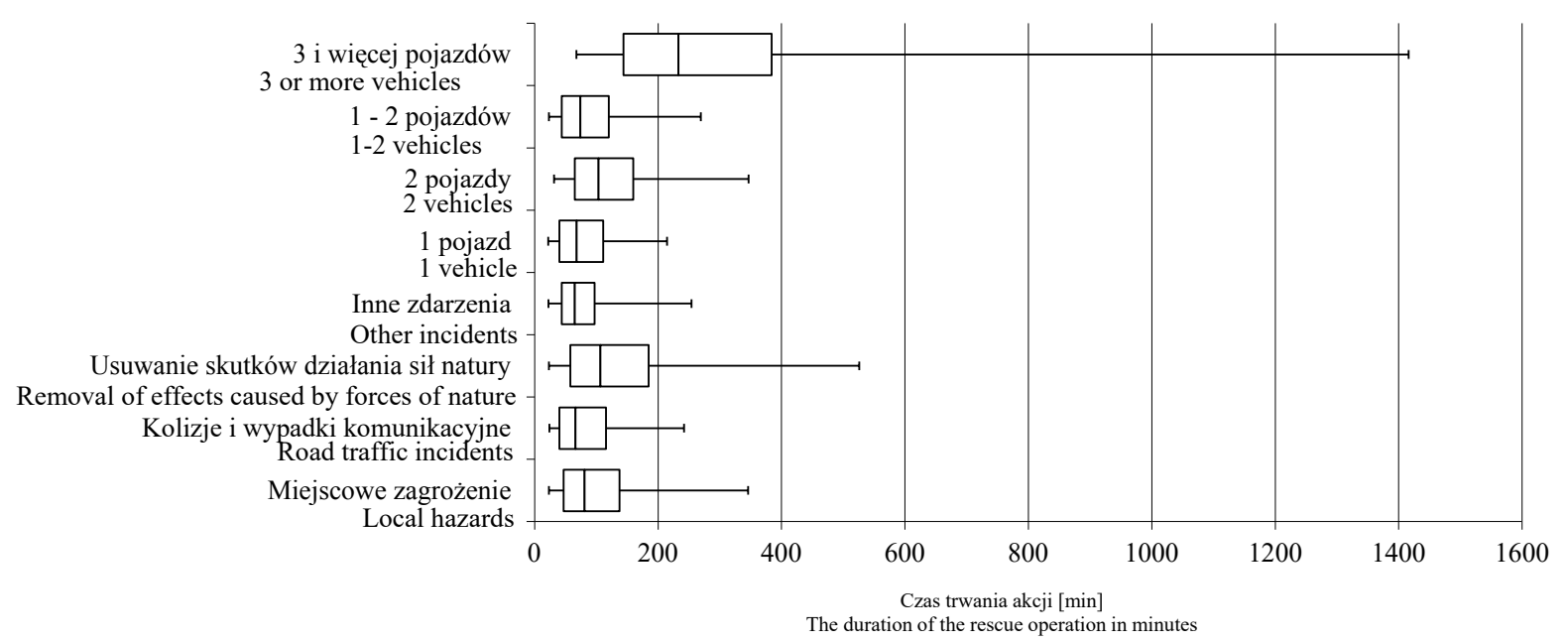

Ryc. 4. Zobrazowanie danych z tabeli 6 . w postaci wykresów skrzynkowych (na wykresach nie uwzględniono kwartylu 0 i 4 )

Fig. 4. Block diagram of data for Table 6 (quartile 0 and 4 excluded from the diagram)

Źródło: Opracowanie własne na podstawie danych z bazy SWD-ST.

Source: Own elaboration on the basis of data from the database SWD-ST.

Z analizy zdarzeń zakwalifikowanych w bazie SWD-ST jako zagrożenia miejscowe, w roku 2009 i 2011 na terenie badanego powiatu można wyciągnąć następujące wnioski:

- brak statystycznie istotnych różnic między przyjętymi wstępnie kategoriami rodzajowymi zdarzeń (kolizje i wypadki komunikacyjne, usuwanie skutków działania sił natury, inne zdarzenia) pod względem takich cech, jak czas trwania akcji ratowniczej i liczba użytych pojazdów;

- statystycznie istotna różnica pojawia się przy analizie czasu prowadzenia akcji ratowniczej - liczbie użytych pojazdów na poziomie do dwóch i więcej.

Uwzględniając powyższe wnioski, przy analizie miejscowych zagrożeń należy wziąć pod uwagę jedynie dwie kategorie wyróżnione liczbą skierowanych do działań ratowniczych pojazdów:

- małe - do dwóch pojazdów, czas trwania działań ratowniczych od 23 do $270 \mathrm{~min}$; mediana $74 \mathrm{~min}$, stanowią one około $90 \%$ zdarzeń;

- duże - powyżej dwóch pojazdów, czas trwania działań ratowniczych od 40 do $800 \mathrm{~min}$; mediana około $200 \mathrm{~min}$, stanowią one około $10 \%$ zdarzeń.

Podział na rodzaje zdarzeń pod względem rodzaju ma sens jedynie w zakresie wyposażenia jednostek ratowniczych. Jednakże dane zawarte w bazie SWD-ST wyraźnie wskazują, że do różnego typu zdarzeń dysponowane są te same pojazdy, co pozwala wnioskować, że ich wyposażenie jest dostosowane do prowadzenia działań ratowniczych we wszystkich wymienionych $\mathrm{w}$ tym sprawozdaniu rodzajach zdarzeń.

\section{Algorytm przestrzennej analizy zagrożeń}

Schemat postępowania przy analizie zagrożeń i ryzyka zdarzeń dyskretnych w proponowanej metodzie obejmuje następujące etapy:

1. przygotowanie i wstępna analiza danych:
- sprawdzenie poprawności danych pod względem formalnym celem eliminacji błędnych danych lub ich poprawienia;

- określenie miejsca zdarzenia w przyjętej konwencji - określenie przybliżonych współrzędnych topograficznych (określenie współrzędnych kwadratu o powierzchni $1 \mathrm{~km}^{2}$, w którym zaszło zdarzenie);

2. kategoryzacja zdarzeń:

- podział zdarzeń na kategorie rodzajowe;

- analiza $\mathrm{ABC}$ pod kątem ilości uczestniczących w akcji ratowniczej pojazdów gaśniczych;

- analiza empirycznych rozkładów czasów trwania akcji ratowniczej, etap ten pozwala odkryć błędne dane, które nie były widoczne w poprzednim etapie;

- zdefiniowanie głównych cech (rodzaj, ilość, czas) dla każdej kategorii zdarzeń;

3. ocena liczności badanych prób:

- sprawdzenie, czy ilość danych w poszczególnych kategoriach spełnia wymogi zakładanej wiarygodności prognoz (wyznaczamy to na podstawie przedziału ufności);

- jeżeli ilość danych nie spełnia wymogu wiarygodności należy zdecydować czy dołączamy dane z lat poprzednich, czy też łączymy kategorie, pamiętając o zachowaniu spójności przynajmniej dwóch cech, które stanowiły podstawę kategoryzacji;

4. przedstawienie na mapie liczby zdarzeń (wartości oczekiwanej) w podziale na poszczególne kategorie;

W dalszej kolejności można dokonać innych analiz dotyczących:

- trendów zmian w liczbie zdarzeń w poszczególnych obszarach - należy dysponować przynajmniej trzema okresami, każdy z ilością danych zapewniających właściwą wiarygodność;

- prognoz liczby zdarzeń w kolejnych latach;

- poprawy wiarygodności prognoz przez podział rozpatrywanego obszaru na podobszary o podobnej 
częstości zdarzeń wybranej kategorii i analizowanie każdego $\mathrm{z}$ nich $\mathrm{z}$ osobna.

Przeznaczeniem wskazanego algorytmu jest opracowanie mapy ryzyka zagrożeń z możliwością predykcji pod kątem oceny adekwatności zorganizowanego systemu ratowniczo-gaśniczego, czyli jego zdolności do skutecznej reakcji adekwatnie do uwarunkowań lokalnych.

\section{Przykład przestrzennej analizy zagrożeń}

Poniżej zaprezentowano wykorzystanie opisanego algorytmu do analizy przestrzennej zdarzeń krytycznych na terenie wybranego powiatu. Dane zaczerpnięto z bazy danych SWD-ST2,5, jednakże dane pozwalające na identyfikację obszaru zostały ukryte.

Analizy dokonano w oparciu o dane zdarzeń krytycznych powiatu z przewagą terenów wiejskich o powierzchni $415 \mathrm{~km}^{2}$. Gęstość zaludnienia wynosi około 105 osób na $\mathrm{km}^{2}$. W miastach mieszka około 1/6 mieszkańców.

Pierwszy etap algorytmu jest trudny do przedstawienia, związany jest on z twórczą pracą analityka. Większość podejmowanych decyzji o usunięciu danych $\mathrm{z}$ analizy jest oparta na intuicji, co prawda uzasadnionej, jednakże uzasadnienie nie musi być akceptowane przez innych analityków. Dlatego też prezentacja algorytmu postępowania rozpocznie się od drugiego etapu - kategoryzacji zdarzeń.
Analizie poddano dane z roku 2008, w którym na terenie badanego powiatu doszło do: 194 pożarów; 148 kolizji i wypadków komunikacyjnych; 107 zdarzeń związanych z działaniem sił natury oraz 228 innych zdarzeń wymagających działań ratowniczych.

Następnym krokiem było dokonanie analizy ABC pod względem liczby zadysponowanych do działań ratowniczych pojazdów gaśniczych. Wyniki tej analizy przedstawiono w tabeli 7.

Na podstawie danych zawartych w tabeli 7 możemy stwierdzić, że zaproponowana powyżej klasyfikacja pożarów na małe, średnie i duże oraz innych zagrożeń miejscowych na małe i duże znajduje potwierdzenie również w statystykach tego powiatu. Badania obejmujące szerszą grupę powiatów wskazują na zasadność przyjętej klasyfikacji. Niewielkie odstępstwa od wyznaczonej reguły występują rzadko i dotyczącą przesunięć granic klasyfikacji o jeden pojazd ratowniczo-gaśniczy.

Dla badanego powiatu możemy stwierdzić, że pożary małe wymagają zadysponowania do dwóch pojazdów gaśniczych, średnie od 3 do 5, a duże powyżej 5. Natomiast $\mathrm{w}$ przypadku innych zagrożeń miejscowych klasyfikacja ta obejmuje jedynie dwie grupy: zagrożenia małe wymagające dysponowania do 2 pojazdów oraz duże powyżej dwóch pojazdów.

Tabela 7. Analiza ABC pod kątem ilości zaangażowanych sił w działania ratownicze z podziałem na rodzajowe kategorie zdarzeń Table 7. ABC Analysis dealing with the volume of resources engaged with salvage operations divided into generic event categories

\begin{tabular}{|c|c|c|c|c|c|c|c|c|c|c|c|c|}
\hline \multirow[b]{2}{*}{ 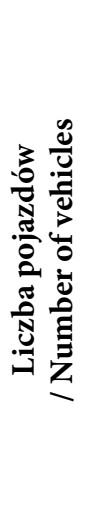 } & \multicolumn{3}{|c|}{ Pożary / Fires } & \multicolumn{3}{|c|}{$\begin{array}{c}\text { Kolizje i wypadki } \\
\text { komunikacyjne } \\
\text { / Road traffic accidents }\end{array}$} & \multicolumn{3}{|c|}{$\begin{array}{c}\text { Usuwanie skutków działania } \\
\text { sił przyrody / Removal of } \\
\text { effects caused by forces of } \\
\text { nature }\end{array}$} & \multicolumn{3}{|c|}{$\begin{array}{l}\text { Inne zdarzenia krytyczne } \\
\text { / Other critical incidents }\end{array}$} \\
\hline & 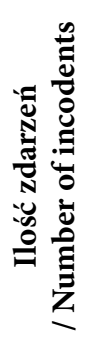 & 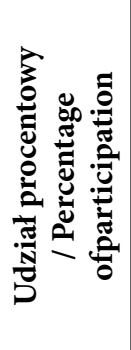 & 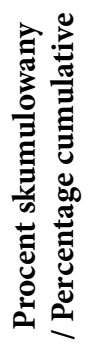 & 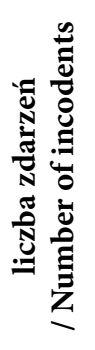 & 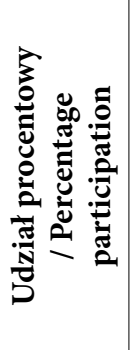 & 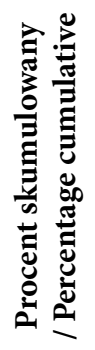 & 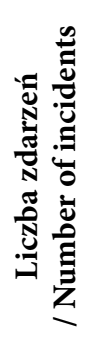 & 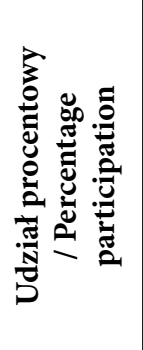 & 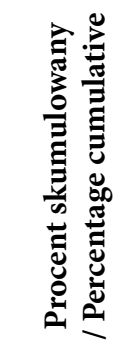 & 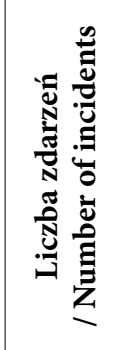 & 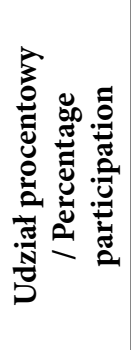 & 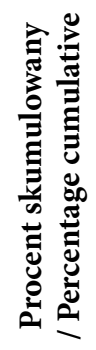 \\
\hline 1 & 85 & $44 \%$ & $44 \%$ & 73 & $49 \%$ & $49 \%$ & 81 & $76 \%$ & $76 \%$ & 205 & $90 \%$ & $90 \%$ \\
\hline 2 & 58 & $30 \%$ & $74 \%$ & 41 & $28 \%$ & $77 \%$ & 22 & $21 \%$ & $96 \%$ & 16 & $7 \%$ & $97 \%$ \\
\hline 3 & 20 & $10 \%$ & $84 \%$ & 25 & $17 \%$ & $94 \%$ & 4 & $4 \%$ & $100 \%$ & 5 & $2 \%$ & $99 \%$ \\
\hline 4 & 7 & $4 \%$ & $88 \%$ & 4 & $3 \%$ & $97 \%$ & & & & 1 & $0 \%$ & $100 \%$ \\
\hline 5 & 8 & $4 \%$ & $92 \%$ & 4 & $3 \%$ & $99 \%$ & & & & & $0 \%$ & $100 \%$ \\
\hline 6 & 10 & $5 \%$ & $97 \%$ & 1 & $1 \%$ & $100 \%$ & & & & 1 & $0 \%$ & $100 \%$ \\
\hline 7 & 3 & $2 \%$ & $98 \%$ & & & & & & & & & \\
\hline 8 & 3 & $2 \%$ & $100 \%$ & & & & & & & & & \\
\hline
\end{tabular}

Źródło: Opracowanie własne na podstawie danych z bazy SWD-ST.

Source: Own elaboration on the basis of data from the database SWD-ST.

Należy jeszcze sprawdzić, czy określone klasy spełniają wymóg rozłączności czasowej trwania działań ratowniczych. Dokonano tego, wykorzystując wykresy pudełkowe i odległość median poszczególnych grup zdarzeń. Jako rozłączne należy traktować te klasy zdarzeń, dla których mediany czasu prowadzenia działań ratowniczych znacznie się różnią. Na ryc. 5, 6, 7, 8 przedstawiono empiryczny rozkład czasu działań ratowniczych z podziałem na określone klasy zdarzeń. W analizie uwzględniono zdarzenia zawierające się w przedziałach percentyl $(0,05)$ do percentyl $(0,95)$. 


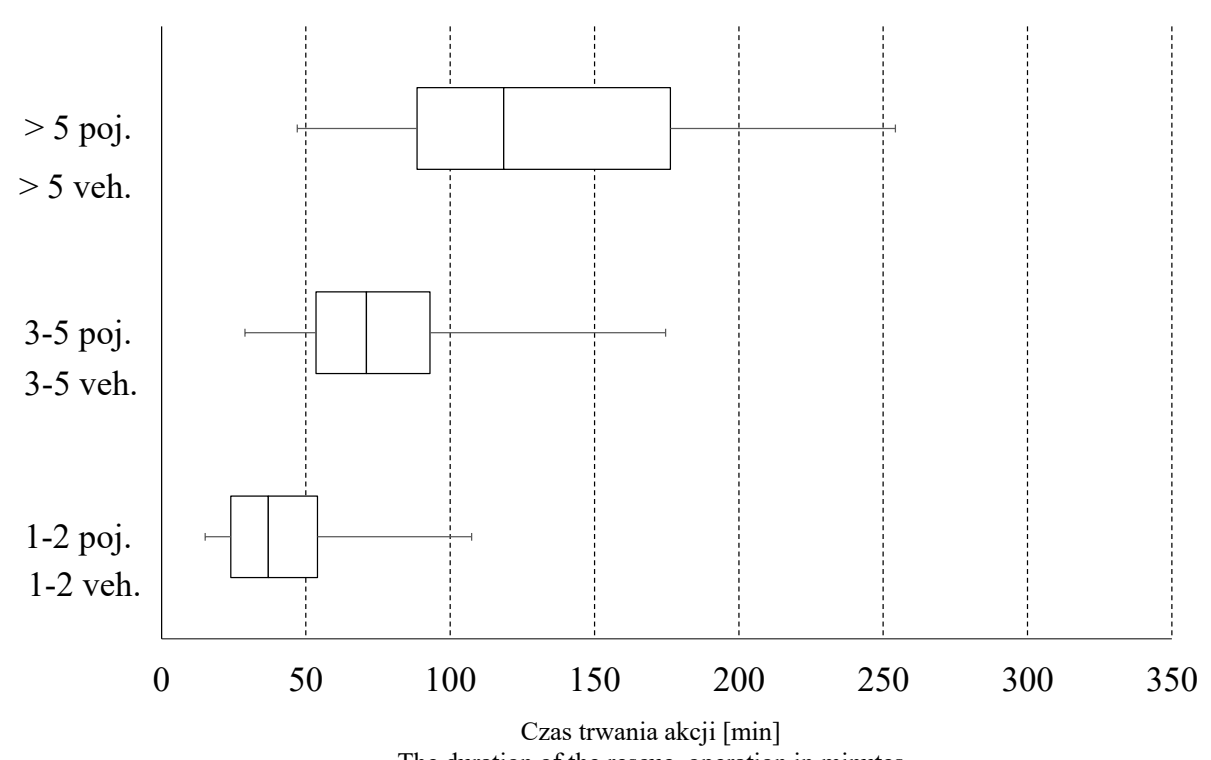

The duration of the rescue operation in minutes

Ryc. 5. Empiryczny rozkład czasu trwania (w minutach) działań ratowniczych w przypadku pożarów z podziałem na kategorie: mały, średni, duży w roku 2008

Fig. 5. Empirical distribution of duration (in minutes), of rescue operations dealing with fires by category: small, medium, large in 2008

Źródło: Opracowanie własne na podstawie danych z bazy SWD-ST. Source: Own elaboration on the basis of data from the database SWD-ST.

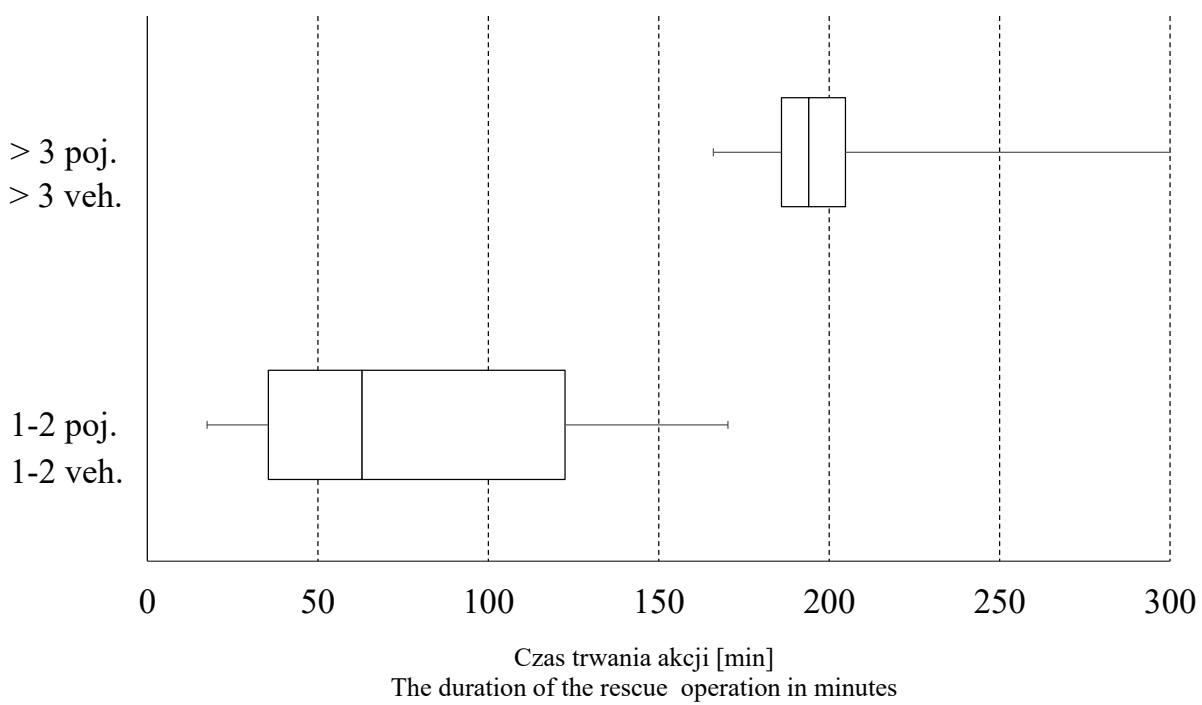

Ryc. 6. Empiryczny rozkład czasu trwania (w minutach) działań ratowniczych w przypadku usuwania skutków działania sił natury z podziałem na kategorie: małe, duże w roku 2008

Fig. 6. Empirical distribution of duration (in minutes) of rescue operations dealing with fires by category: small, medium, large in 2008

Źródło: Opracowanie własne na podstawie danych z bazy SWD-ST

Source: Own elaboration on the basis of data from the database SWD-ST. 


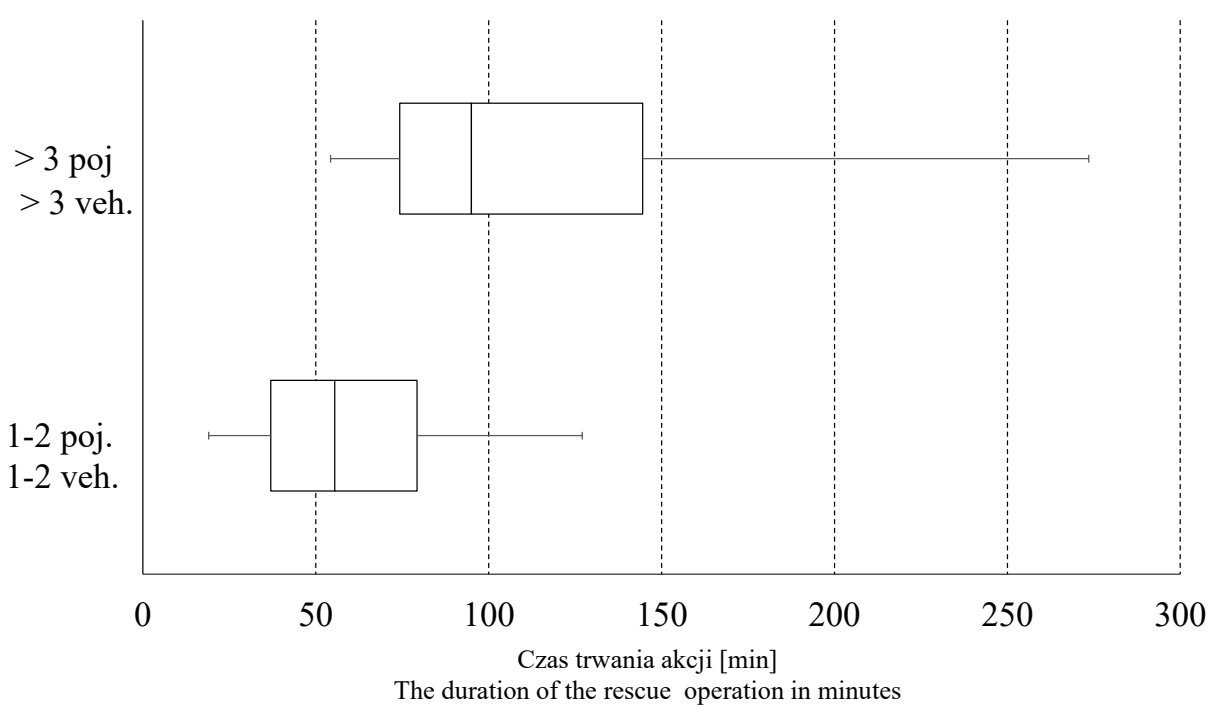

Ryc. 7. Empiryczny rozkład czasu trwania (w minutach) działań ratowniczych w przypadku kolizji i wypadków komunikacyjnych z podziałem na kategorie: małe, duże w roku 2008

Fig. 7. Empirical distribution of duration (in minutes), of rescue operations dealing with road traffic accidents by category: small, large in 2008

Źródło: Opracowanie własne na podstawie danych z bazy SWD-ST.

Source: Own elaboration on the basis of data from the database SWD-ST.

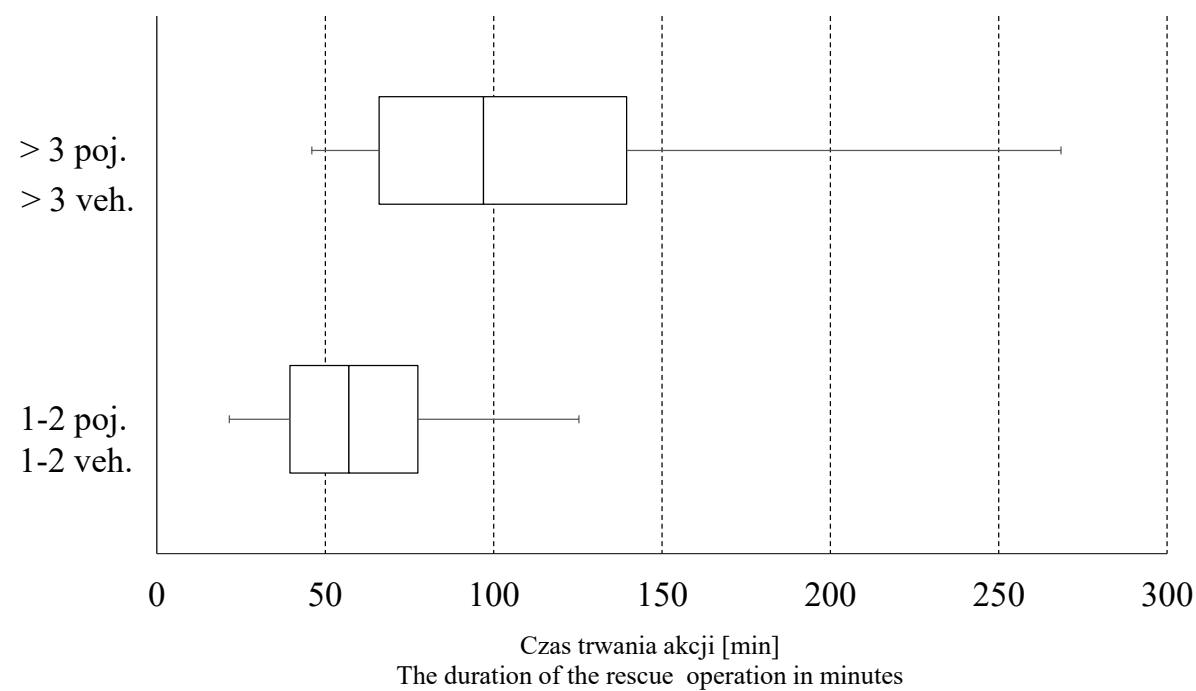

Ryc. 8. Empiryczny rozkład czasu trwania (w minutach) działań ratowniczych w przypadku innych zagrożeń miejscowych z podziałem na kategorie: małe, duże w roku 2008

Fig. 8. Empirical distribution of duration (in minutes), of rescue operations dealing with other local threats by category: small, large in 2008

Źródło: Opracowanie własne na podstawie danych z bazy SWD-ST.

Source: Own elaboration on the basis of data from the database SWD-ST.

Z zaprezentowanych danych wynika, że czas działań ratowniczych w przypadku kolizji i wypadków komunikacyjnych oraz innych zagrożeń jest niemal identyczny. Natomiast w przypadku usuwania skutków działania sił przyrody czas działań ratowniczych jest nieco dłuższy.

Na podstawie zaprezentowanych wykresów możemy dokonać następującej klasyfikacji zdarzeń krytycznych na terenie badanego powiatu:
1. Pożary:
- małe - liczba zaangażowanych pojazdów gaśniczych do 2, czas trwania akcji ratowniczej zawiera się

w przedziale od $15 \mathrm{~min}$ do $107 \mathrm{~min}$, na poziomie ufności 0,9; mediana $37 \mathrm{~min}$; stanowią one około $80 \%$ wszystkich pożarów w danym roku;

- średnie - liczba zaangażowanych pojazdów gaśniczych od 3 do 5, czas trwania akcji ratowniczej zawiera się w przedziale od $29 \mathrm{~min}$ do $175 \mathrm{~min}$, na poziomie ufności 0,9; mediana $71 \mathrm{~min}$; stanowią one około $15 \%$ wszystkich pożarów w danym roku;

- duże - liczba zaangażowanych pojazdów gaśniczych powyżej 5, czas trwania akcji ratowniczej zawiera się w przedziale od $47 \mathrm{~min}$ do $250 \mathrm{~min}$, na poziomie 
ufności 0,9; mediana 118 min; stanowią one około $5 \%$ wszystkich pożarów w danym roku;

2. Usuwanie skutków działania sił natury:

- małe - do dwóch pojazdów, czas trwania działań ratowniczych od 17 do $240 \mathrm{~min}$, na poziomie ufności 0,9; mediana $63 \mathrm{~min}$; stanowią one około 90\% zdarzeń;

- duże - powyżej dwóch pojazdów, czas trwania działań ratowniczych od 180 do $213 \mathrm{~min}$, na poziomie ufności 0,9; mediana około $200 \mathrm{~min}$; stanowią one około $10 \%$ zdarzeń.

3. Kolizje i wypadki drogowe:

- małe - do dwóch pojazdów, czas trwania działań ratowniczych od 20 do $120 \mathrm{~min}$, na poziomie ufności 0,9; mediana $55 \mathrm{~min}$; stanowią one około $90 \%$ zdarzeń;

- duże - powyżej dwóch pojazdów, czas trwania działań ratowniczych od 55 do $273 \mathrm{~min}$, na poziomie ufności 0,9 ; mediana około $95 \mathrm{~min}$; stanowią one około $10 \%$ zdarzeń.
4. Inne zdarzenia krytyczne:

- małe - do dwóch pojazdów, czas trwania działań ratowniczych od 19 do $140 \mathrm{~min}$, na poziomie ufności 0,9; mediana 57 min; stanowią one około $90 \%$ zdarzeń;

- duże - powyżej dwóch pojazdów, czas trwania działań ratowniczych od 38 do $156 \mathrm{~min}$, na poziomie ufności 0,9 ; mediana około $97 \mathrm{~min}$; stanowią one około $10 \%$ zdarzeń.

Wykorzystując powyższą klasyfikację, dokonano przestrzennej analizy zagrożeń na terenie badanego powiatu w oparciu o dane z $2008 \mathrm{r}$. Analizie poddano pożary małe i średnie oraz małe miejscowe zagrożenia. Pominięto zdarzenia duże ze względu na ich sporadyczność - zbyt małą ilość danych. Analizowane kategorie zdarzeń krytycznych stanowią 95\% wszystkich zdarzeń, a zatem ich analiza jest reprezentatywna dla badanego obszaru. Wyniki analizy przedstawiono w tabeli 8 .

Tabela 8. Analiza przestrzenna zdarzeń krytycznych (małych i średnich) za 2008 r. (kwadrat jednostkowy - obszar wyznaczony przez linie siatki topograficznej 1992)

Table 8. Spatial analysis of critical incidents (SMEs) for year 2008 (unit square - an area designated by the grid lines in 1992)

\begin{tabular}{|c|c|c|c|c|c|c|c|c|}
\hline \multicolumn{3}{|c|}{ Miejsce / Location } & \multicolumn{6}{|c|}{ Kategorie zdarzeń / Incident category (level) } \\
\hline 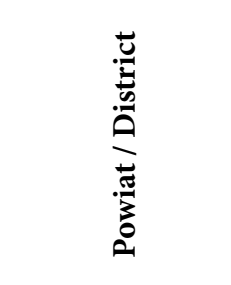 & 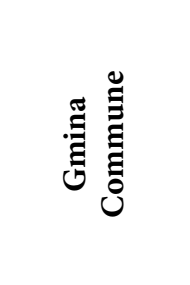 & 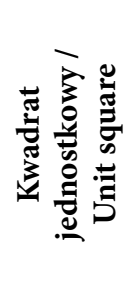 & 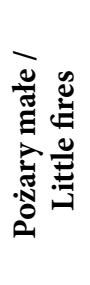 & 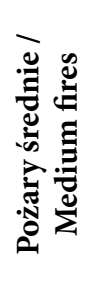 & 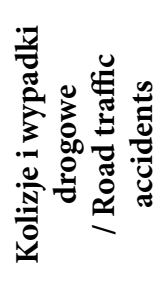 & 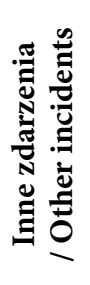 & 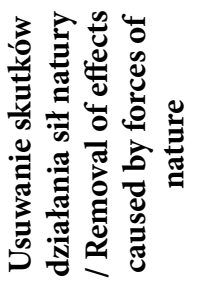 & 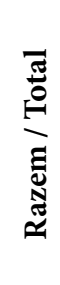 \\
\hline \multirow[t]{28}{*}{ Powiat / District } & & & 143 & 35 & 114 & 221 & 103 & 616 \\
\hline & \multirow{22}{*}{$\begin{array}{c}\text { Gmina I } \\
\text { Commune I }\end{array}$} & & 8 & 2 & 19 & 37 & 13 & 79 \\
\hline & & 1 & & & & 1 & & 1 \\
\hline & & 2 & & & & 1 & & 1 \\
\hline & & 3 & & & 1 & 1 & & 2 \\
\hline & & 4 & & & 2 & 1 & 1 & 4 \\
\hline & & 5 & 1 & & & & & 1 \\
\hline & & 6 & & & & 1 & & 1 \\
\hline & & 7 & & & & 3 & & 3 \\
\hline & & 8 & & & & 3 & & 3 \\
\hline & & 9 & & & 1 & 5 & 2 & 8 \\
\hline & & 10 & 1 & 1 & & 2 & 1 & 5 \\
\hline & & 11 & 1 & & 3 & 1 & 1 & 6 \\
\hline & & 12 & & & 1 & & 1 & 2 \\
\hline & & 13 & & & & 1 & & 1 \\
\hline & & 14 & & & 3 & 3 & 1 & 7 \\
\hline & & 15 & & & 1 & 3 & 3 & 7 \\
\hline & & 16 & 1 & & & 1 & & 2 \\
\hline & & 17 & & & 2 & 4 & 2 & 8 \\
\hline & & 18 & 1 & & & & & 1 \\
\hline & & 19 & & & 1 & & & 1 \\
\hline & & 20 & 2 & 1 & & 1 & 1 & 5 \\
\hline & & 21 & 1 & & 4 & 5 & & 10 \\
\hline & \multirow{5}{*}{$\begin{array}{c}\text { Gmina II } \\
\text { Commune II }\end{array}$} & & 13 & 6 & 13 & 36 & 4 & 72 \\
\hline & & 1 & 7 & 1 & 4 & 8 & 2 & 22 \\
\hline & & 2 & & & & 1 & & 1 \\
\hline & & 3 & 1 & & & & & 1 \\
\hline & & 4 & 1 & & 4 & 2 & & 7 \\
\hline
\end{tabular}




\begin{tabular}{|c|c|c|c|c|c|c|c|c|}
\hline \multicolumn{3}{|c|}{ Miejsce / Location } & \multicolumn{6}{|c|}{ Kategorie zdarzeń / Incident category (level) } \\
\hline 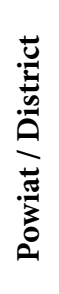 & 莺 & 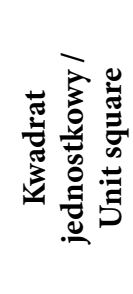 & 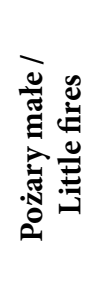 & 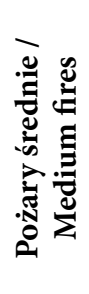 & 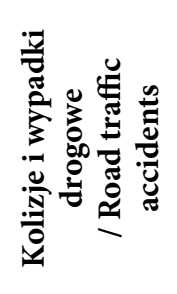 & 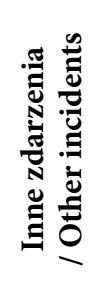 & 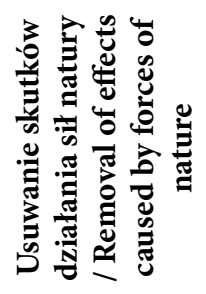 & 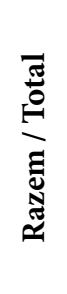 \\
\hline & & 5 & & 1 & & 1 & & 2 \\
\hline & & 6 & 1 & 1 & & 3 & & 5 \\
\hline & & 7 & 1 & & & 1 & & 2 \\
\hline & & 8 & 1 & 1 & & & & 2 \\
\hline & & 9 & & 1 & 2 & & & 3 \\
\hline & & 10 & 1 & 1 & & 2 & & 4 \\
\hline & & 11 & & & & 2 & 1 & 3 \\
\hline & & 12 & & & 1 & & & 1 \\
\hline & & 13 & & & & 2 & & 2 \\
\hline & & 14 & & & & 4 & & 4 \\
\hline & & 15 & & & 1 & 2 & 1 & 4 \\
\hline & & 16 & & & 1 & 8 & & 9 \\
\hline & \multirow{15}{*}{$\begin{array}{c}\text { Gmina III } \\
\text { Commune III }\end{array}$} & & 63 & 13 & 24 & 38 & 24 & 162 \\
\hline & & 1 & & & & & 1 & 1 \\
\hline & & 2 & 6 & 1 & 4 & 4 & 2 & 17 \\
\hline & & 3 & 1 & 2 & & 3 & 1 & 7 \\
\hline & & 4 & 1 & 1 & & 1 & & 3 \\
\hline & & 5 & 3 & & & & 1 & 4 \\
\hline & & 6 & 31 & 4 & 11 & 17 & 13 & 76 \\
\hline & & 7 & 4 & & & 3 & & 7 \\
\hline & & 8 & & & & 1 & & 1 \\
\hline & & 9 & 11 & 4 & 6 & 0 & 3 & 24 \\
\hline & & 10 & 4 & & & 1 & & 5 \\
\hline & & 11 & 1 & 1 & & 1 & & 3 \\
\hline & & 12 & 1 & & 3 & 3 & 3 & 10 \\
\hline & & 13 & & & & 3 & & 3 \\
\hline & & 14 & & & & 1 & & 1 \\
\hline & \multirow{10}{*}{$\begin{array}{c}\text { Gmina IV } \\
\text { Commune IV }\end{array}$} & & 3 & 1 & 1 & 4 & 14 & 23 \\
\hline & & 1 & 2 & & & & 5 & 7 \\
\hline & & 2 & & & & & 2 & 2 \\
\hline & & 3 & 1 & & & 2 & & 3 \\
\hline & & 4 & & 1 & & 1 & & 2 \\
\hline & & 5 & & & & 1 & 4 & 5 \\
\hline & & 6 & & & & & 1 & 1 \\
\hline & & 7 & & & 1 & & & 1 \\
\hline & & 8 & & & & & 1 & 1 \\
\hline & & 9 & & & & & 1 & 1 \\
\hline & \multirow{13}{*}{$\begin{array}{c}\text { Gmina V } \\
\text { Commune V }\end{array}$} & & 49 & 9 & 51 & 93 & 39 & 241 \\
\hline & & 1 & 0 & & 1 & & & 1 \\
\hline & & 2 & 2 & & & & & 2 \\
\hline & & 3 & & & & 1 & & 1 \\
\hline & & 4 & 1 & & 2 & 1 & & 4 \\
\hline & & 5 & & 1 & 1 & & & 2 \\
\hline & & 6 & & & 1 & & & 1 \\
\hline & & 7 & & & 2 & 1 & & 3 \\
\hline & & 8 & 29 & 2 & 30 & 34 & 14 & 109 \\
\hline & & 9 & 4 & & 2 & 14 & 4 & 24 \\
\hline & & 10 & 3 & & 3 & 5 & 3 & 14 \\
\hline & & 11 & & & 1 & 2 & 1 & 4 \\
\hline & & 12 & 2 & & 4 & 6 & & 12 \\
\hline
\end{tabular}




\begin{tabular}{|c|c|c|c|c|c|c|c|c|}
\hline \multicolumn{3}{|c|}{ Miejsce / Location } & \multicolumn{6}{|c|}{ Kategorie zdarzeń / Incident category (level) } \\
\hline 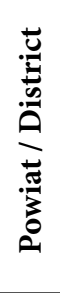 & 芯 & 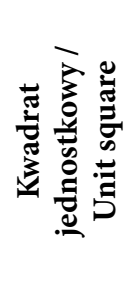 & 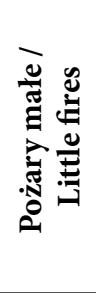 & 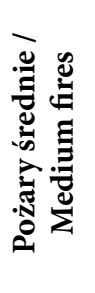 & 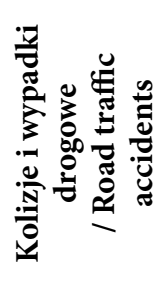 & 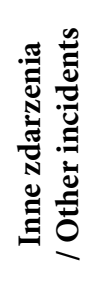 & 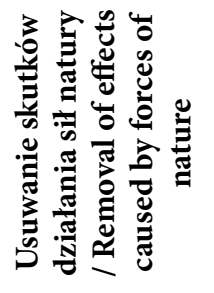 & 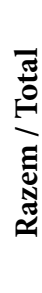 \\
\hline & & 13 & & & 1 & 2 & 4 & 7 \\
\hline & & 14 & 1 & 1 & & 2 & & 4 \\
\hline & & 15 & 1 & & & & 1 & 2 \\
\hline & & 16 & 1 & & & 1 & & 2 \\
\hline & & 17 & & & & 1 & & 1 \\
\hline & & 18 & 1 & & & 2 & 1 & 4 \\
\hline & & 19 & & & & 3 & 1 & 4 \\
\hline & & 20 & & 1 & & 3 & & 4 \\
\hline & & 21 & 1 & 1 & 1 & 2 & 3 & 8 \\
\hline & & 22 & & & 1 & 2 & & 3 \\
\hline & & 23 & & 1 & & 3 & 6 & 10 \\
\hline & & 24 & 2 & & & 1 & 1 & 4 \\
\hline & & 25 & & 1 & & 3 & & 4 \\
\hline & & 26 & 1 & 1 & & 4 & & 6 \\
\hline & & 27 & & & 1 & & & 1 \\
\hline & & & 7 & 4 & 6 & 13 & 9 & 39 \\
\hline & Gmina vi & 1 & & & & & 1 & 1 \\
\hline & Commune VI & 2 & & 1 & 1 & & & 2 \\
\hline & & 3 & 1 & 1 & 1 & 2 & & 5 \\
\hline & & 4 & 1 & & & 4 & & 5 \\
\hline & & 5 & 2 & & 1 & 1 & 7 & 11 \\
\hline & & 6 & & 2 & 1 & 2 & & 5 \\
\hline & & 7 & 1 & & & & & 1 \\
\hline & & 8 & 2 & & 2 & 4 & 1 & 9 \\
\hline
\end{tabular}

Źródło: Opracowanie własne na podstawie danych z bazy SWD-ST.

Source: Own elaboration on the basis of data from the database SWD-ST.

Przeprowadzona analiza prowadzi do dość zaskakujących wniosków:

- $30 \%$ zdarzeń krytycznych miało miejsce w dwóch kwadratach jednostkowych (powierzchnia $2 \mathrm{~km}^{2}$ - gmina III kw. 6; gmina V kw. 8);

- zdarzenia krytyczne zanotowano na obszarze $82 \mathrm{kwa}-$ dratów jednostkowych (20\% powierzchni powiatu)

- $30 \%$ zdarzeń krytycznych wystąpiło na $0,5 \%$ powierzchni powiatu.

Powyższe wnioski wskazują, iż szczególne zagrożenie wystąpieniem zdarzeń krytycznych dotyczy zaledwie niewielkiej powierzchni powiatu. Sugeruje to, że w tych kwadratach jednostkowych występują szczególne warunki sprzyjające pojawianiu się zdarzeń krytycznych. Być może pewne zmiany infrastrukturalne poprawiłyby znacznie bezpieczeństwo na tych obszarach. Należałoby zatem przeanalizować owe uwarunkowania i skonstruować właściwą politykę prewencyjną.

Istotnym i zaskakującym faktem jest również czas prowadzenia działań ratowniczych gaśniczych w skali roku, który wynosił 1513 godz., co stanowi 17\% czasu, jakim dysponowały zespoły ratownicze. Obliczeń dokonano przy założeniu, że działania ratownicze trwały zawsze maksymalny czas określony dla danej kategorii. Jeżeli uwzględnimy, iż średnio czas działań ratowniczych był równy medianie tego czasu dla poszczególnych kategorii, to wówczas wykorzystanie czasu dyspozycji zespołów ratowniczych wynosiło zaledwie $6,3 \%$. Należy oczywiście pamiętać, że analizujemy jedynie zdarzenia, do których zadysponowano nie więcej niż dwa pojazdy gaśnicze.

Zdaniem autorów ciekawym zagadnieniem jest udzielenie odpowiedzi na następujące pytanie: jakie jest prawdopodobieństwo, że w czasie prowadzenia działań ratowniczych pojawi się kolejne zdarzenie krytyczne? Jego rozwiązanie wymaga nieco innej formuły: jakie jest prawdopodobieństwo, że czas oczekiwania na kolejne zdarzenie krytyczne będzie mniejszy niż maksymalny czas prowadzenia działań ratowniczych? Tak sformułowane pytanie możemy zapisać w następującej postaci matematycznej:

$$
p(t<T)=1-e^{-\lambda T}
$$

Gdzie: $\lambda$ - częstość zdarzeń w jednostce czasu; $\mathrm{T}$ - czas oczekiwania na kolejne zdarzenie.

$\mathrm{W}$ badanym powiecie w skali roku wystąpiło $616 \mathrm{zda}-$ rzeń krytycznych, a zatem liczba zdarzeń w ciągu jednej minuty wynosi 0,00117. Maksymalny czas trwania działań ratowniczych w przypadku usuwania skutków działania sił 
natury wynosi $240 \mathrm{~min}$, stąd prawdopodobieństwo pojawienia się kolejnego zdarzenia krytycznego w tym czasie wynosi 0,245 - jest ono bardzo niskie. Zdarzenia tej kategorii nie są dominujące. Stanowią one jedynie $16 \%$ wszystkich zdarzeń. Dominujące są inne zdarzenia krytyczne (36\% wszystkich zdarzeń). Dla nich czas trwania działań ratowniczych wynosi 140 min przy poziomie ufności 0,95. Przy tego typu zdarzeniach prawdopodobieństwo pojawienia się kolejnego w trakcie prowadzenia działań ratowniczych wynosi zaledwie 0,15. Można zatem stwierdzić, iż utrzymywanie przez ten powiat dwóch zespołów ratowniczych (pojazd ratowniczo-gaśniczy wraz załogą, dyspozycyjny 24 godz. na dobę - trzy obsady osobowe), jest nieuzasadnione ekonomicznie. Wynika to z małej efektywności działania, która w przypadku zdarzeń małych i średnich wynosi zaledwie 15\%. Zdarzenia duże wymagają zaangażowania znacznie większych sił i środków. Należy zatem liczyć się z potrzebą wykorzystania zewnętrznych sił i środków. Zdarzenia tego typu stanowią zaledwie 5\% wszystkich zdarzeń krytycznych w skali roku, czyli dla badanego powiatu jest to zaledwie 30 zdarzeń w roku.

\section{Podsumowanie}

Przeprowadzenie właściwej kategoryzacji zdarzeń krytycznych pozwala na bardziej wnikliwą analizę przestrzenną zagrożeń. Jej efekty można wykorzystać zarówno w budowaniu strategii prewencyjnej, jak i konstruowaniu właściwej struktury systemu ratowniczo-gaśniczego. Pomaga ona również w ocenie efektywności (w ujęciu ekonomicznym) przyjętych rozwiązań organizacyjnych i zbudowanego potencjału służb ratowniczych.

Artykuł został opracowany w ramach projektu nr DOBR/0015/R/ID1/2012/03 pt. „Zaawansowane technologie teleinformatyczne wspomagające projektowanie systemu ratowniczego na poziomach: gmina, powiat, województwo" realizowanego przez konsorcjum naukowe ze środków finansowych Narodowego Centrum Badań i Rozwoju (konkurs nr 3/2012 na wykonanie projektów w zakresie badań naukowych lub prac rozwojowych na rzecz obronności i bezpieczeństwa państwa).

\section{Literatura}

[1] Guerriero V., Iannace A., Mazzoli S., Parente M., Vitale S., Giorgioni M.., Quantifying uncertainties in multi-scale studies offractured reservoir analogues: Implemented statistical analysis of scan line data from carbonate rocks, „Journal of Structural Geology”, 2009.

[2] Koronacki J., Mielniczuk J., Statystyka dla studentów kierunków technicznych i przyrodniczych, WNT, Warszawa 2006.

[3] Prońko J., Bezpieczeństwo, zagrożenie, kryzys w kontekście kierowania organizacjami, AON, Warszawa 2011.

[4] Prońko J., Zarządzanie ryzykiem w obszarze bezpieczeństwa powszechnego, Wyższa Szkoła Administracji, Bielsko-Biała 2010.

[5] Reducing risiks, protecting people. HSE's decision - making process, Norwich: Her Majesty's Stationery Office, 2001. HSE.

[6] Ronald J. Evans, J. Boersma, N. M. Blachman, A.A. Jagers. The Entropy of a Poisson Distribution: Problem 87-6. "SIAM Review” Vol. 30 Issue 2.

[7] Wawrzynek J, Metody opisu i wnioskowania statystycznego, Wydawnictwo Akademii Ekonomicznej im. Oskara Langego we Wrocławiu, Wrocław 2007.

dr hab. inż. Jarosław Prońko - profesor nadzwyczajny Instytutu Zarządzania Uniwersytetu Jana Kochanowskiego w Kielcach. Absolwent Politechniki Świętokrzyskiej i AON. Były oficer Nadwiślańskich Jednostek Wojskowych. Uczestnik akcji przeciwpowodziowej w 1997 r. - odznaczony Krzyżem Zasługi za Dzielność. W latach 1998-2001 główny specjalista w Biurze Spraw Obronnych MSWiA. Autor i współautor wielu prac z zakresu bezpieczeństwa powszechnego, zarządzania kryzysowego, problematyki podejmowania decyzji oraz analizy ryzyka w obszarze bezpieczeństwa powszechnego.

st. bryg. w st. sp. mgr inż. Jan Kielin - w 1968 r. ukończył Szkołę Oficerów Pożarnictwa w Warszawie, a w 1977 r. Wyższą Oficerską Szkołę Pożarniczą w Warszawie. W latach 1981-1983 odbył studia magisterskie w Wyższej Szkole Pedagogicznej w Krakowie. W roku 1975 uzyskał uprawnienia rzeczoznawcy do spraw zabezpieczeń przeciwpożarowych. Autor wielu publikacji z zakresu bezpieczeństwa pożarowego (m.in. Poradnik dla Specjalisty Ochrony Przeciwpożarowej, Materiały szkoleniowe dla pracowników zakładów pracy) oraz tłumaczeń (z j. niemieckiego) z zakresu ochrony przeciwpożarowej.

mgr Beata Wojtasiak - absolwentka Akademii Pedagogiki Specjalnej im. Marii Grzegorzewskiej w Warszawie (Wydział Nauk Pedagogicznych). W 2013 r. ukończyła studia podyplomowe Menedżer Innowacji w Szkole Głównej Handlowej w Warszawie. Aktualnie pracownik Jednostki Certyfikującej Centrum Naukowo-Badawczego Ochrony Przeciwpożarowej - Państwowego Instytutu Badawczego na stanowisku mł. specjalista inżynieryjno-techniczny. 